\title{
The Raam regional soil moisture monitoring network in the Netherlands
}

\author{
Harm-Jan F. Benninga ${ }^{1}$, Coleen D. U. Carranza ${ }^{2}$, Michiel Pezij ${ }^{3}$, Pim van Santen ${ }^{4}$, \\ Martine J. van der Ploeg ${ }^{2}$, Denie C. M. Augustijn ${ }^{3}$, and Rogier van der Velde \\ ${ }^{1}$ Department of Water Resources, Faculty of Geo-Information Science and Earth \\ Observation, University of Twente, 7500 AE Enschede, the Netherlands \\ ${ }^{2}$ Soil Physics and Land Management Group, Department of Environmental \\ Sciences, Wageningen University, 6700 AA Wageningen, the Netherlands \\ ${ }^{3}$ Water Engineering and Management, Faculty of Engineering Technology, \\ University of Twente, 7500 AE Enschede, the Netherlands \\ ${ }^{4}$ Waterschap Aa en Maas, 5216 PP 's-Hertogenbosch, the Netherlands \\ Correspondence: Harm-Jan F. Benninga (h.f.benninga@utwente.nl)
}

Received: 7 June 2017 - Discussion started: 13 July 2017

Revised: 1 November 2017 - Accepted: 3 November 2017 - Published: 11 January 2018

\begin{abstract}
We have established a soil moisture profile monitoring network in the Raam region in the Netherlands. This region faces water shortages during summers and excess of water during winters and after extreme precipitation events. Water management can benefit from reliable information on the soil water availability and water storing capacity in the unsaturated zone. In situ measurements provide a direct source of information on which water managers can base their decisions. Moreover, these measurements are commonly used as a reference for the calibration and validation of soil moisture content products derived from earth observations or obtained by model simulations. Distributed over the Raam region, we have equipped 14 agricultural fields and 1 natural grass field with soil moisture and soil temperature monitoring instrumentation, consisting of Decagon 5TM sensors installed at depths of 5, 10, 20, 40 and $80 \mathrm{~cm}$. In total, 12 stations are located within the Raam catchment (catchment area of $223 \mathrm{~km}^{2}$ ), and 5 of these stations are located within the closed sub-catchment Hooge Raam (catchment area of $41 \mathrm{~km}^{2}$ ). Soil-specific calibration functions that have been developed for the 5TM sensors under laboratory conditions lead to an accuracy of $0.02 \mathrm{~m}^{3} \mathrm{~m}^{-3}$. The first set of measurements has been retrieved for the period 5 April 2016-4 April 2017. In this paper, we describe the Raam monitoring network and instrumentation, the soil-specific calibration of the sensors, the first year of measurements, and additional measurements (soil temperature, phreatic groundwater levels and meteorological data) and information (elevation, soil physical characteristics, land cover and a geohydrological model) available for performing scientific research. The data are available at https://doi.org/10.4121/uuid:dc364e97-d44a-403f-82a7-121902deeb56.
\end{abstract}

\section{Introduction}

Soil moisture is a hydrological state variable that affects various processes on global, regional and local scales. On the global to regional scales, the control of soil moisture on the exchanges of water and heat at the land surface plays an important role in the development of weather and climate systems (Global Climate Observing System, 2010; Seneviratne et al., 2010). Therefore, the Global Climate Observing
System initiative (2010) has identified soil moisture as an essential climate variable. However, soil moisture products from state-of-the-art land surface models (LSMs) show large biases compared to in situ observations (Xia et al., 2014; Zheng et al., 2015) and large variation among different models (Dirmeyer et al., 2006; Xia et al., 2014). Xia et al. (2014) pointed out that, in particular, the soil moisture outcomes from LSMs need improvement. In situ observations help to 
identify the shortcomings of LSMs and to improve model descriptions of related processes.

Soil moisture also affects numerous hydrological and ecological processes that are essential for a wide spectrum of applications on the regional to local scales. Regional water management can benefit from timely and reliable information about soil moisture content: it can improve quantifications of flood risks by its effect on rainfall estimations and streamflow predictions (Beck et al., 2009; Massari et al., 2014; Wanders et al., 2014) and negative anomalies to current plant water demands are an indicator of (the onset of) droughts (Carrão et al., 2016; Wilhite and Glantz, 1985). The agricultural sector depends on sufficient root zone soil water availability for crop growth, while excess of soil water leads to severe losses (Feddes et al., 1978). In addition, wet soil conditions are unfavourable for the trafficability of farmlands, which can jeopardize the timely execution of essential agricultural practices and cause structural damage of land (Batey, 2009; Hamza and Anderson, 2005; Schwilch et al., 2016). Lastly, information about soil moisture content is relevant to assess the effects of groundwater extractions (Ahmad et al., 2002), drainage systems and irrigation systems.

Soil moisture content conditions can be quantified using in situ instruments (Starr and Paltineanu, 2002; Vereecken et al., 2014), earth observations (Kornelsen and Coulibaly, 2013; Petropoulos et al., 2015) and land process models subject to atmospheric forcing terms (Albergel et al., 2012; De Lange et al., 2014; Srivastava et al., 2015; Vereecken et al., 2008). Of these methods, in situ instruments are the most accurate and can have a high temporal resolution when automated, but they lack spatial support. In contrast, earth observations and process models provide areal estimates and enable the quantification of soil moisture across large spatial domains, but uncertainties regarding their soil moisture estimates are still the subject of investigation. The success of soil moisture estimation from earth observations depends on the specifications of the sensor, the assumptions and parameter values adopted for the retrieval algorithms, and the soil and vegetation cover conditions (e.g. Burgin et al., 2017; Chan et al., 2016; Das et al., 2014; Kerr et al., 2016; Pathe et al., 2009). Earth observations in the microwave spectrum, which are most often used for the estimation of soil moisture by earth observations (Kornelsen and Coulibaly, 2013; Petropoulos et al., 2015), originate from the soil surface to $0.01-0.05 \mathrm{~m}$ depth (Escorihuela et al., 2010; Kornelsen and Coulibaly, 2013; Nolan and Fatland, 2003; Rondinelli et al., 2015; Ulaby et al., 1996). Measurement depth is controlled by the microwave wavelength, sensor type (active or passive) and moisture conditions (Escorihuela et al., 2010; Nolan and Fatland, 2003; Rondinelli et al., 2015; Ulaby et al., 1996). However, the relation between surface soil moisture and soil moisture at deeper layers is complicated. To relate surface soil moisture to soil moisture at greater depths, the correct specification of hydraulic parameters and modelling of the hydrological processes are required (Chen et al.,
2011; Das and Mohanty, 2006; Vereecken et al., 2008). Yet, several studies have reported that surface soil moisture may provide information about soil moisture at greater depths (Das and Mohanty, 2006; Ford et al., 2014; Vereecken et al., 2008). Estimations of vegetation characteristics by microwave and optical sensors also have the potential to provide estimates of root zone soil moisture (Van Emmerik et al., 2015; Petropoulos et al., 2015; Steele-Dunne et al., 2012; Wang et al., 2010). Regarding land process models, the implemented model physics, model structure, the quality of parameterizations, and the imposed initial and boundary conditions (including atmospheric forcing terms) determine the reliability of model results (Xia et al., 2014). Combining observations of earth variables with process models by data assimilation techniques is interesting in estimating initial model states, model state updating and parameter calibration, thereby improving the model accuracy (Houser et al., 2012; Reichle, 2008; Vereecken et al., 2008).

In situ soil moisture content measurements provide a reference for validating earth observation retrievals and land process models. The combination of in situ measurements at various depths, earth observation products and land process models is essential to obtaining reliable soil moisture information at the temporal, horizontal and vertical resolutions required for the above-mentioned applications. Several regional-scale soil moisture monitoring networks have been established to fulfil (part of) this aim. The International Soil Moisture Network (Dorigo et al., 2011) and the SMAP $\mathrm{Cal} /$ Val Partner Sites (Colliander et al., 2017) are two initiatives that bring together the data collected by a number of networks. The Natural Resources Conservation Service Soil Climate Analysis Network, consisting of 218 stations in agricultural areas across the United States of America, is operationally used for monitoring drought development, developing mitigation policies, predicting the long-term sustainability of cropping systems and watershed health, predicting regional shifts in irrigation water requirements, and predicting changes in runoff (U.S. Department of Agriculture, 2016). Examples of regional-scale networks in a temperate climate are the Little Washita (Cosh et al., 2006) and Little River (Bosch et al., 2007) networks in North America, REMEDHUS in Spain (Martínez-Fernández and Ceballos, 2005), Twente in the Netherlands (Dente et al., 2011, 2012; Van der Velde et al., 2014), HOBE's network in Denmark (Bircher et al., 2012), SMOSMANIA in France (Albergel et al., 2008; Calvet et al., 2007), TERENO in Germany (Zacharias et al., 2011), and Kyeamba (Smith et al., 2012) in Australia. This paper presents the soil moisture and soil temperature profile monitoring network in the Raam region, in the southeast of the Netherlands, established in April 2016. By Dutch standards and in comparison to the only existing long-term soil moisture monitoring network in the Netherlands, in the Twente region (Dente et al., 2011, 2012; Van der Velde et al., 2014), the Raam region faces substantial water shortages during summers. Extreme precipitation events 


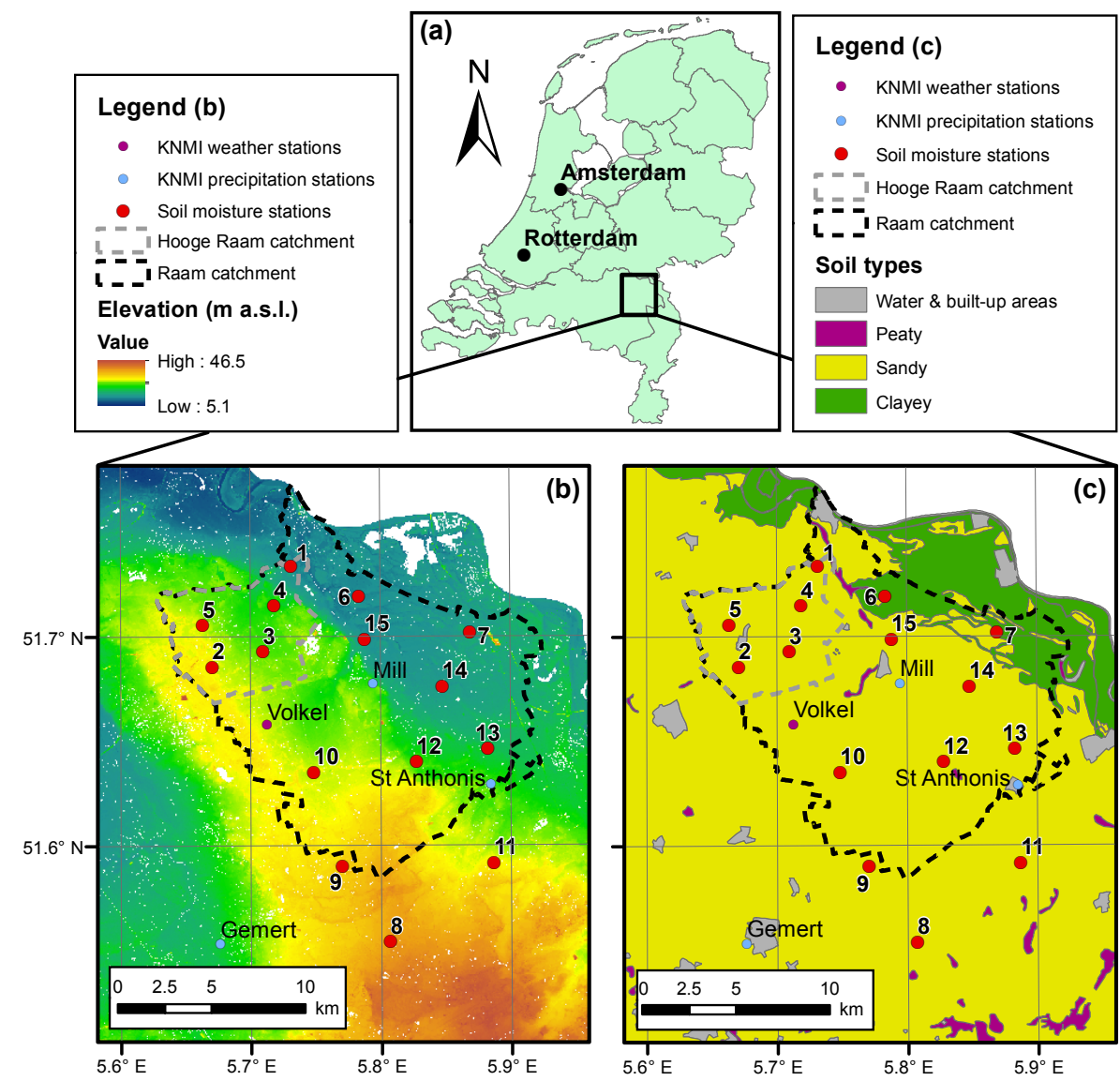

Figure 1. (a) Location of the Raam study area (black box) in the Netherlands. (b) Digital elevation model (Actueel Hoogtebestand Nederland, 2016). (c) Major soil types classes (BOFEK2012; Wösten et al., 2013).

cause an excess of water and inundation of fields. These extreme situations present a challenge for the intensive agriculture in the region: the agricultural yield largely depends on the applied water management. The Raam soil moisture monitoring network is established jointly with the regional water management authority, Waterschap Aa en Maas. With the network, we aim to collect data for the calibration and validation of earth observation soil moisture products, the assessment of land process model performance and the understanding of processes affected by soil moisture (e.g. field trafficability, crop water availability). In addition, cooperation with the regional water management authority enables the exploration of the potential of soil moisture information for optimizing operational regional water management. In this paper, we describe the characteristics of the Raam catchment (Sect. 2), the network design and instrumentation (Sect. 3), the sensor's propagation distance (Sect. 4.1), the sensor calibration results (Sect. 4.2), the verification of the first year of measurements (Sect. 4.3), and data availability and additional data available for scientific research (Sect. 5).

\section{Study area}

The Raam River is situated in the southeast of the Netherlands (Fig. 1a), has a catchment area of $223 \mathrm{~km}^{2}$ and is a tributary of the Meuse River. The catchment has a temperate oceanic climate. For the period 2000-2016, on average, the coldest month is January $\left(3.3^{\circ} \mathrm{C}\right)$ and the warmest month is July $\left(18.3^{\circ} \mathrm{C}\right)$, based on measurements at Volkel weather station (Royal Netherlands Meteorological Institute (KNMI), 2017). Annual precipitation statistics are listed in Table 1. Figure 2a shows the monthly precipitation measured at the Volkel weather station averaged for the period 2000-2015 and for the hydrological year 2016. Figure $2 \mathrm{~b}$ shows the cumulative precipitation deficit for the hydrological year 2016 and the average for the period 2000-2015. The cumulative precipitation deficit is calculated by subtracting daily reference evapotranspiration rates from the daily precipitation measured at the Volkel weather station and summing the daily deficits. A number of heavy precipitation events characterized May 2016 to August 2016, which caused the 2016 summer in the Raam area to be wetter than normal. In dry years, the cumulative precipitation deficit can reach up to 
Table 1. Precipitation statistics of the KNMI weather and precipitation stations for the period 2000-2016 (KNMI, 2017).

\begin{tabular}{lccc}
\hline Station & $\begin{array}{c}\text { Average annual } \\
\text { precipitation }(\mathrm{mm})\end{array}$ & $\begin{array}{c}\text { Minimum annual } \\
\text { precipitation }(\mathrm{mm})\end{array}$ & $\begin{array}{c}\text { Maximum annual } \\
\text { precipitation }(\mathrm{mm})\end{array}$ \\
\hline Volkel (hourly measurements) & 767 & 681 & 862 \\
Mill (daily measurements) & 850 & 692 & 949 \\
St. Anthonis (daily measurements) & 830 & 689 & 954 \\
Gemert (daily measurements) & 826 & 688 & 940 \\
\hline
\end{tabular}
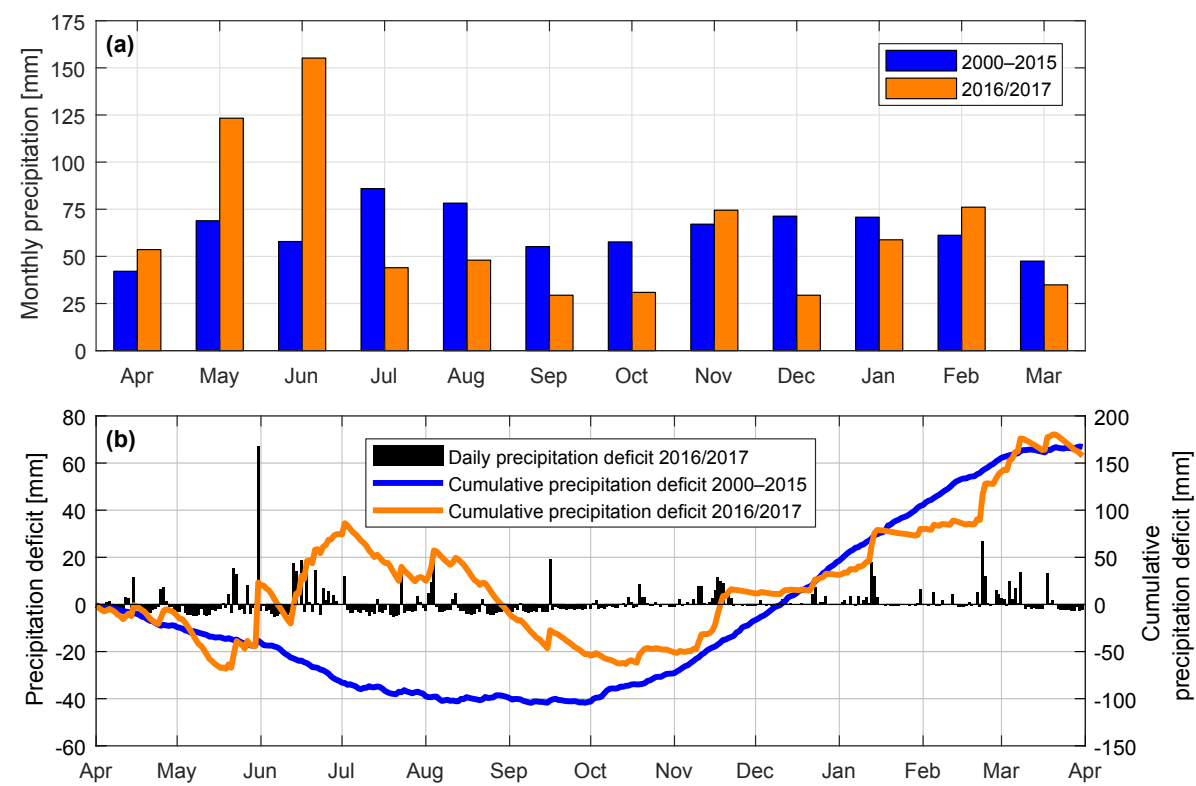

Figure 2. (a) Average monthly precipitation for the period 2000-2015 and the monthly precipitation in the hydrological year 2016 measured at Volkel weather station. (b) Daily and cumulative precipitation deficits for the period 2000-2015 and for the hydrological year 2016, based on precipitation measurements and reference evapotranspiration calculations at Volkel weather station.

$100 \mathrm{~mm}$ in summer. During these dry periods, farmers irrigate from deep groundwater reservoirs. The regional water management authority operates a system of weirs and pumping stations to minimize situations of excess water and droughts. In addition, the regional water management authority continuously discharges surface water into the southern part of the catchment to increase groundwater recharge. The average discharge into the catchment for the summer of 2016 was $900 \mathrm{~m}^{3} \mathrm{~h}^{-1}$.

The subsurface of the Raam catchment consists of unconsolidated Pleistocene sandy and fluvial gravel sediments in two river terraces. The higher terrace slopes gently from 21 to $17 \mathrm{~m}$ a.s.1., and the lower terrace slopes from 13 to $8 \mathrm{~m}$ a.s.1., with the terrace edge lying in a northwest-southeast direction (Fig. 1b). Remnants of peat and fine sands, deposited by aeolian processes, are found on the higher terrace. In parts of the study area, anthropogenic activities - the continuous addition of straw-mixed cattle droppings - have elevated fields, resulting in an approximately $1 \mathrm{~m}$ thick layer of brown earth with high organic matter contents, called plaggen soils (Blume and Leinweber, 2004). The soil map in Fig. 1c shows that the soils in the catchment are mostly sandy, with loam contents varying from 0 to about $20 \%$ (Wösten et al., 2013). In the eastern part, loamy and clayey soils are present. The main land cover types are grassland (30\%) and corn fields $(20 \%)$, another $14 \%$ is used for other crops, built-up and paved areas occupy $14 \%$, forests cover about $10 \%$, and open water covers $3 \%$.

Several northwest-southeast-orientated dip-slip faults are present in the subsurface, as shown in Fig. 3. Movements along these faults have caused the formation of sharp lateral transitions between highly permeable and impermeable layers, as shown in Fig. 4. On the eastern part of the higher terrace (D-E in Figs. 3 and 4) this has resulted in the existence of a phreatic aquifer only $10 \mathrm{~m}$ thick, whereas for the rest of the study area the phreatic aquifer is generally around 25 to $50 \mathrm{~m}$ thick. The sharp transition in aquifer thickness leads to obstruction of the northeast-directed groundwater flow and high groundwater levels on the western part of the higher terrace $(\mathrm{C}-\mathrm{D})$, as shown in Fig. 3 . 


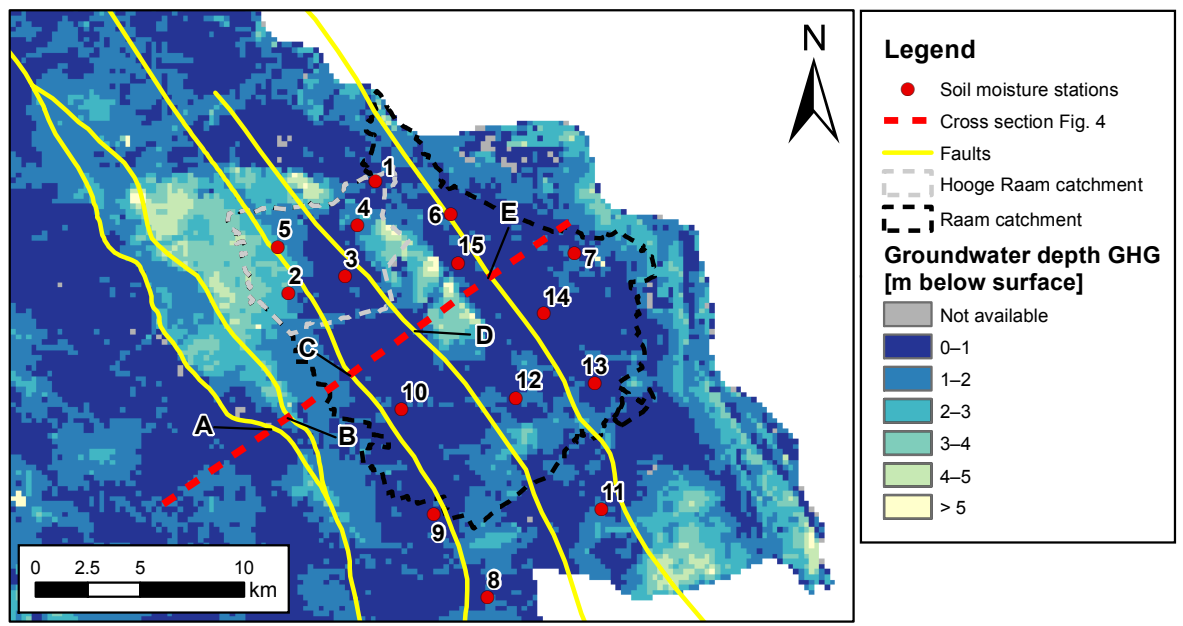

Figure 3. Mean highest groundwater depth ("gemiddeld hoogste grondwaterstand", GHG) in the Raam catchment. The GHG is a long-term average of highest groundwater depths, defined as the average of the three highest groundwater depths per year over a period of 8 years. The groundwater data originate from the national implementation of the Netherlands Hydrological Instrument, NHI LHM (De Lange et al., 2014). The map also shows the location of faults in the area. The dashed red line represents the cross section that is shown in Fig. 4.

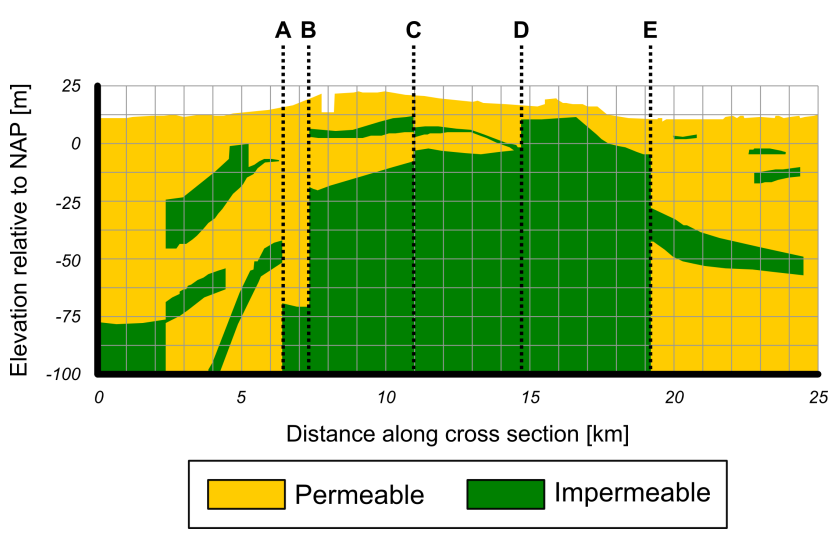

Figure 4. West-east cross section of the Raam catchment showing the permeable and impermeable layers of the subsoil, based on the geohydrological model REGIS II (Vernes and Van Doorn, 2005). The locations indicated by A, B, C, D and E refer to the position of the faults and correspond to the letters in Fig. 3.

\section{Network design}

\subsection{Station locations}

In April 2016, 15 stations were installed in the Raam region (Fig. 1). The locations capture the range of physical characteristics influencing the area's hydrological dynamics. The physical characteristics considered are soil texture (Sect. 3.1.1), land cover (Sect. 3.1.2) and elevation (Sect. 3.1.3). Stations 1 to 7,10 and 12 to 15 are located within the Raam catchment. Stations 1 to 5 are located in a closed sub-catchment of the Raam catchment, called the Hooge Raam catchment ("The High Raam"). With 15 stations distributed over a $495 \mathrm{~km}^{2}$ area, the network's density is approximately $33 \mathrm{~km}^{2}$ per station. The density is $18.6 \mathrm{~km}^{2}$ per station within the Raam catchment and $8.2 \mathrm{~km}^{2}$ per station within the Hooge Raam catchment. The number of stations and the density of the Raam network are comparable to soil moisture monitoring networks that are comparable in areal extent, such as the Little Washita network (20 stations, $30 \mathrm{~km}^{2}$ average spacing), the Fort Cobb network (15 stations, $23 \mathrm{~km}^{2}$ average spacing), the Reynolds Creek network (15 stations, $16 \mathrm{~km}^{2}$ average spacing), the Little River network (33 stations, $10 \mathrm{~km}^{2}$ average spacing), the Kyeamba network (14 stations, $43 \mathrm{~km}^{2}$ average spacing) and the Adelong Creek network (5 stations, $29 \mathrm{~km}^{2}$ average spacing) (Crow et al., 2012). Crow et al. (2012) stated that these regional-scale networks provide information over a range of land covers and on a scale that allows the validation of operational soil moisture products from earth observations, such as from the Advanced Scatterometer (ASCAT) at 25 and $50 \mathrm{~km}$ (Wagner et al., 2013), the Advanced Microwave Scanning Radiometer (AMSR-2) at 0.1 and $0.25^{\circ}$ (Zhang et al., 2017), the Soil Moisture and Ocean Salinity satellite (SMOS) at $43 \mathrm{~km}$ (Kerr et al., 2016) and the Soil Moisture Active Passive satellite (SMAP) at $40 \mathrm{~km}$ resolution (Chan et al., 2016). Basinscale aggregates are expected to have root mean square error ( $E_{\mathrm{RMS}}$ ) values of $0.01 \mathrm{~m}^{3} \mathrm{~m}^{-3}$ (Crow et al., 2012), which is small compared to the $E_{\mathrm{RMS}}$ goal of $0.04 \mathrm{~m}^{3} \mathrm{~m}^{-3}$ defined for the SMOS mission (Kerr et al., 2010) and SMAP mission (Chan et al., 2016). Besides, in hydrological research there is a trend towards hyperresolution land surface modelling (Beven et al., 2015; Wood et al., 2011). Wood et al. (2011) proposed developing land surface models on continental scales with a grid resolution of $100 \mathrm{~m}$ by $100 \mathrm{~m}$. An example of a high-resolution model is the Landelijk Hydrologisch Model (LHM) application of the Netherlands Hydro- 
logical Instrument (NHI), which is currently operating at a spatial resolution of $250 \mathrm{~m}$ by $250 \mathrm{~m}$ (De Lange et al., 2014). To facilitate the development of such high-resolution models, networks with a high density are required.

\subsubsection{Soil texture}

The Raam catchment mainly holds sandy soils. Therefore, 13 stations were positioned in coarse sandy soils. Two stations (stations 6 and 7) were positioned in clayey sands and loamy sands respectively, at the northeastern part of the study area. Table 2 lists the soil type descriptions adopted from BOFEK2012. BOFEK2012 provides the soil physical characteristics (e.g. soil texture, water retention curve and hydraulic conductivity curve) for the soil units in the Netherlands, based on the Dutch class pedotransfer functions known as the Staring series (Wösten et al., 2001, 2013). Table 2 also lists the corresponding World Reference base soil order (Hartemink and De Bakker, 2006).

Complementing the available soil texture information, we performed particle size analyses in a laboratory, following the pipette method described by Van Reeuwijk (2002), on samples representing the upper $40 \mathrm{~cm}$ of the soil profile at each monitoring station. Organic matter content was determined by the loss of ignition method (Davies, 1974; Hoogsteen et al., 2015) at $500^{\circ} \mathrm{C}$. The results reveal very high sand contents for most stations, and as expected, stations 6 and 7 have higher volume fractions of silt and clay. The results are consistent with the BOFEK2012 class descriptions.

\subsubsection{Land cover}

For practical reasons, the monitoring stations were installed at the border of fields. Table 3 lists the land cover of the adjacent fields in 2016 as well as the land cover at the exact location of the monitoring stations in 2016. Positioning of stations on agricultural areas was preferred over forest and natural areas. Microwave remote-sensing instruments are typically unable to observe the soil under dense forest canopies, so measurements at agricultural areas are the most valuable for validating soil moisture retrievals from earth observations. Furthermore, agricultural areas in particular are manageable regarding water-related processes. Station 6 was positioned in natural grassland.

\subsubsection{Elevation}

The stations were distributed in such a way that they cover the elevation gradient of the catchment. This will be valuable for observing the influence of groundwater level and waterlimited evapotranspiration conditions on soil moisture.

\subsection{Instrumentation}

Common instruments to measure volumetric soil moisture content are based on time-domain reflectometry (TDR) or
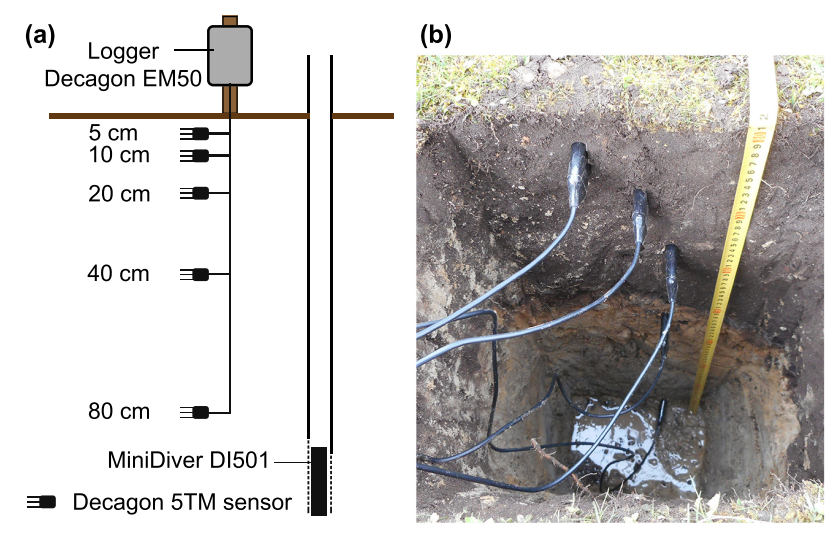

Figure 5. (a) Schematic cross section of the soil moisture monitoring stations and nearby phreatic groundwater level monitoring well. (b) Photo of an installation pit with the soil moisture sensors installed at the five depths.

capacitance techniques. Capacitance sensors are the most attractive choice for networks consisting of multiple soil moisture monitoring stations because of their relatively low costs, ease of operation and applicability to a wide range of soil types (Bogena et al., 2007; Kizito et al., 2008; Vereecken et al., 2014). We deploy the Decagon 5TM capacitance sensor in the Raam network. The 5TM and other Decagon sensors that use the same technique and frequency have been widely used for in situ soil moisture networks and have proved to fulfil the performance requirements (Bircher et al., 2012; Bogena et al., 2010; Dente et al., 2009, 2011; Kizito et al., 2008; Matula et al., 2016; Varble and Chávez, 2011; Vaz et al., 2013).

5TM sensors use an oscillator operating at $70 \mathrm{MHz}$ to measure the capacitance of the soil, which is affected by the soil's relative dielectric permittivity. The sensor prongs charge the surrounding soil, and the time needed to fully charge the soil defines the capacitance and consequently the relative dielectric permittivity of the soil. The relative dielectric permittivity of the soil varies as a function of the volumetric soil moisture content. Decagon Devices (2016) reports the following specifications for the 5TM: the resolution of the soil moisture measurements is $0.0008 \mathrm{~m}^{3} \mathrm{~m}^{-3}$, and the accuracy is $\pm 0.03 \mathrm{~m}^{3} \mathrm{~m}^{-3}$ for mineral soils by applying the function established by Topp et al. (1980) to convert relative dielectric permittivity to volumetric soil moisture content. A thermistor on the same probe measures soil temperature. The resolution of the temperature measurements is $0.1^{\circ} \mathrm{C}$, and the accuracy is $\pm 1{ }^{\circ} \mathrm{C}$.

The sensors are installed horizontally, with the prongs in vertical orientation to avoid ponding on the sensors due to water infiltration or condensation of vapour (Fig. 5). Soil moisture and temperature are logged every 15 min with Decagon Em50 data loggers. At each location we installed 5TM sensors at depths of 5, 10, 20, 40 and $80 \mathrm{~cm}$ (Fig. 5). 
Table 2. Characteristics of the soil moisture monitoring stations.

\begin{tabular}{|c|c|c|c|c|c|c|}
\hline Station & Soil description ${ }^{\mathrm{a}}$ & Soil order ${ }^{b}$ & $\begin{array}{l}\text { Sand fraction } \\
(>50 \mu \mathrm{m})(\%)\end{array}$ & $\begin{array}{l}\text { Silt fraction } \\
(50-2 \mu \mathrm{m})(\%)\end{array}$ & $\begin{array}{l}\text { Clay fraction } \\
(<2 \mu \mathrm{m})(\%)\end{array}$ & $\begin{array}{l}\text { Organic matter } \\
\text { fraction }(\%)\end{array}$ \\
\hline 1 & $\begin{array}{l}\text { Weakly loamy sandy soil on } \\
\text { subsoil of coarse sand ( } 305)\end{array}$ & Podzols & 91.3 & 1.9 & 3.5 & 3.3 \\
\hline 2 & $\begin{array}{l}\text { Weakly loamy sandy soil on } \\
\text { subsoil of coarse sand ( } 305)\end{array}$ & Podzols & 90.4 & 3.7 & 2.1 & 3.8 \\
\hline 3 & $\begin{array}{l}\text { Weakly loamy Podzol soil } \\
\text { (304) }\end{array}$ & Podzols & 93.3 & 2.4 & 1.9 & 2.4 \\
\hline 5 & $\begin{array}{l}\text { Weakly loamy sandy soil } \\
\text { with thick man-made earth } \\
\text { soil ( } 311)\end{array}$ & Anthrosols & 93.1 & 2.3 & 1.1 & 3.5 \\
\hline 6 & $\begin{array}{l}\text { Clayey sand on sand (flu- } \\
\text { vial) (409) }\end{array}$ & Anthrosols/Vague soils & 83.7 & 4.8 & 9.9 & 1.6 \\
\hline 8 & $\begin{array}{l}\text { Weakly loamy Podzol soil } \\
\text { (304) }\end{array}$ & Podzols & 92.8 & 1.6 & 1.4 & 4.1 \\
\hline 9 & $\begin{array}{l}\text { Weakly loamy Podzol soil } \\
\text { (304) }\end{array}$ & Podzols & 95.4 & 1.1 & 0.8 & 2.6 \\
\hline 10 & $\begin{array}{l}\text { Weakly loamy Podzol soil } \\
\text { (304) }\end{array}$ & Podzols & 96.3 & 0.8 & 0.7 & 2.2 \\
\hline 11 & $\begin{array}{l}\text { Weakly loamy Podzol soil } \\
(304)\end{array}$ & Podzols & 94.8 & 1.7 & 1.6 & 1.9 \\
\hline 12 & $\begin{array}{l}\text { Weakly loamy Podzol soil } \\
(304)\end{array}$ & Podzols & 92.0 & 2.5 & 1.7 & 3.9 \\
\hline 13 & $\begin{array}{l}\text { Weakly loamy soil partly on } \\
\text { subsoil of coarse sand (309) }\end{array}$ & Podzols & 96.7 & 1.1 & 0.8 & 1.4 \\
\hline
\end{tabular}

a Soil description and classification code from BOFEK2012 (Wösten et al., 2013).

b Approximate soil order equivalent in the World Reference base (Hartemink and De Bakker, 2006).

Next to all monitoring stations, phreatic groundwater levels are monitored by Waterschap Aa en Maas at an hourly time interval or by the Province of Noord-Brabant at a daily time interval with a MiniDiver DI501 (Schlumberger Water Services, 2014).

\subsection{Zone of influence of 5TM sensors}

For practical reasons, the shallowest in situ sensors are typically installed at $5 \mathrm{~cm}$ depth (Rondinelli et al., 2015; Shellito et al., 2016). In air, 5TM sensors integrate a volume of $715 \mathrm{~mL}$ around the prongs, with a maximum distance of $6 \mathrm{~cm}$ from the centre of the sensor (Cobos, 2015). This means that open air above the soil surface would affect the sensor readings at $5 \mathrm{~cm}$. In soil, which has a higher dielectric permittivity, the outer edge will be closer to the sensor (Cobos, 2015). Sakaki et al. (2008) and Cobos (2015) investigated the mea- surement volume in air and Vaz et al. (2013) in deionized water by moving the sensor towards/from a front of water and air. We conducted the same kind of experiment with a soil sample from station 1. A steel knife, which has an extremely high dielectric permittivity, was inserted into a soilfilled container with a 5TM sensor buried in the middle. The steel knife was brought towards the 5TM sensor from the direction similar to where the soil surface would be in the field. With this experiment we were able to leave the 5TM sensor in the same position to eliminate effects other than the steel knife. This procedure was performed five times for a range of soil moisture conditions.

\subsection{Calibration}

To convert sensor readings to volumetric soil moisture content we use a two-step calibration procedure (Bogena et al., 
Table 3. Land cover of adjacent fields and at the locations of the soil moisture monitoring stations.

\begin{tabular}{lll}
\hline Station & $\begin{array}{l}\text { Land cover of the ad- } \\
\text { jacent field(s) in 2016 }\end{array}$ & $\begin{array}{l}\text { Land cover at the lo- } \\
\text { cation of the station in } \\
2016\end{array}$ \\
\hline 1 & Grass & Grass \\
2 & Sugar beets & Grass \\
3 & Grass & Grass \\
4 & Grass & Grass \\
5 & Onions & Grass fallow \\
6 & Natural grass & Natural grass \\
7 & Corn and Cichorium & Grass fallow \\
8 & Sugar beets & Grass \\
9 & Sugar beets & Grass fallow \\
10 & Grass & Grass \\
11 & Corn and grass & Grass \\
12 & Grass & Grass \\
13 & Corn & Grass \\
14 & Grass & Grass \\
15 & Grass & Grass \\
\hline
\end{tabular}

2007; Rosenbaum et al., 2010). The first step is the conversion of the sensor reading to relative dielectric permittivity. Kizito et al. (2008) concluded that there is no significant probe-to-probe variability among Decagon $\mathrm{ECH}_{2} \mathrm{O}$-TE sensors, and Rosenbaum et al. (2010) found an $E_{\mathrm{RMS}}$ of approximately $0.01 \mathrm{~m}^{3} \mathrm{~m}^{-3}$ as a result of Decagon 5TE probe-toprobe variability. Decagon Devices calibrate each 5TM sensor to account for probe-to-probe variability and to provide a linear relation between the sensor's response and the real part of the relative dielectric permittivity (Rosenbaum et al., 2010):

$\varepsilon_{\mathrm{a}}=\frac{5 \mathrm{TM}_{\mathrm{reading}}}{50}$,

where $5 \mathrm{TM}_{\text {reading }}(\mathrm{mV})$ is the raw output of the $5 \mathrm{TM}$ and $\varepsilon_{\mathrm{a}}$ $(-)$ is the relative dielectric permittivity.

The second step is converting relative dielectric permittivity to volumetric soil moisture content. The relation between relative dielectric permittivity and soil moisture is affected by soil composition, bulk density, organic matter content and soil salinity (Starr and Paltineanu, 2002). Relative dielectric permittivity can be converted to soil moisture using a general calibration function or using a soil-specific calibration function. By default the Decagon ECH2O Utility software applies the Topp function (Topp et al., 1980). However, Vaz et al. (2013) stated that soil-specific calibration is often recommended to address the various soil property effects. According to Decagon Devices (2016) the accuracy can be improved from \pm 0.03 to $\pm 0.01-0.02 \mathrm{~m}^{3} \mathrm{~m}^{-3}$ by using a soil-specific calibration function. Indeed, several studies concluded that soil-specific calibration can significantly improve the accuracy (Sect. 4.2, Table 6).

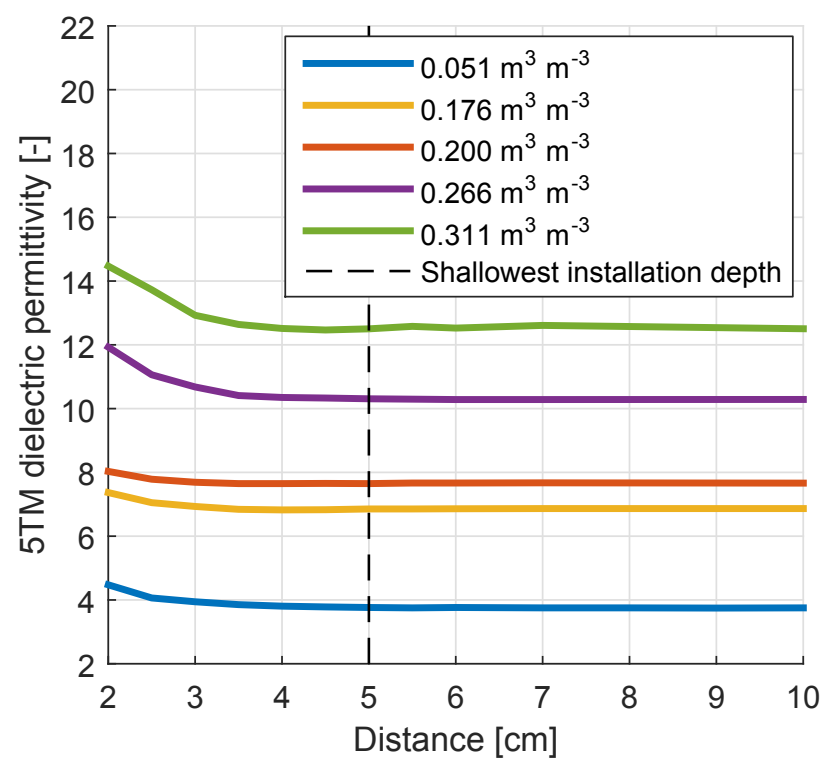

Figure 6. Dielectric permittivity readings of a 5TM sensor in a soil sample from station 1 , obtained by moving a steel knife towards the sensor. The lines are the average of measurements obtained by performing the procedure described in Sect. 3.3 five times for each of the soil moisture conditions.

We developed soil-specific calibration functions for the main soil types present in the study area, by analysing soil samples taken from stations 1,7 and 10 . The soil texture at these stations is considered representative of the soils at other stations; see Table 4. The measurements to establish the calibration function were collected following the procedure described by Starr and Paltineanu (2002), as recommended by Decagon Devices (Cobos and Chambers, 2010). The procedure employs pairs of gravimetrically determined volumetric soil moisture (GVSM) and sensor readings of relative dielectric permittivity. The GVSMs and 5TM measurements were obtained under laboratory conditions in disturbed soil samples, while gradually wetting the soil from air-dried conditions to saturated conditions by adding 75 to $100 \mathrm{~mL}$ of water. In every session typically 15 to 18 pairs of measurements were collected. The described procedure has been performed three times for each of the three soil samples.

The capability of the calibration functions to reproduce GVSM with 5TM measurements is evaluated with Spearman's rank correlation coefficient $r_{\mathrm{s}}, E_{\mathrm{RMS}}$ and the bias, which we define as

bias $=\frac{1}{n} \sum_{i=1}^{n} \theta_{5 \mathrm{TM}}(i)-\frac{1}{n} \sum_{i=1}^{n} \theta_{\mathrm{GVSM}}(i)$,

where $\theta_{5 \mathrm{TM}}\left(\mathrm{m}^{3} \mathrm{~m}^{-3}\right)$ is the $5 \mathrm{TM}$ soil moisture reading converted by a calibration function and $\theta_{\mathrm{GVSM}}\left(\mathrm{m}^{3} \mathrm{~m}^{-3}\right)$ is the reference GVSM. 
Table 4. Calibration coefficients for converting relative dielectric permittivity measurements by 5TM sensors to volumetric soil moisture content.

\begin{tabular}{llccc}
\hline \multirow{2}{*}{ Station } & Representative of stations & \multicolumn{3}{c}{ Coefficients } \\
\cline { 3 - 5 } & & $A$ & $B$ & $C$ \\
\hline 1 & $1,2,4,5,8,12,14,15$ & 1.276 & 0.1310 & -1.466 \\
7 & 6,7 & 0.4853 & 0.2571 & -0.6427 \\
10 & $3,9,10,11,13$ & 24.16 & 0.007038 & -24.33 \\
\hline
\end{tabular}

Table 5. Accuracy metrics between the GVSMs and 5TM readings converted to volumetric soil moisture content with the Topp function and the soil-specific calibration functions.

\begin{tabular}{|c|c|c|c|c|c|c|c|}
\hline \multirow[t]{2}{*}{ Station } & \multicolumn{3}{|c|}{ Topp function } & \multirow[t]{2}{*}{$\mathrm{N}$} & \multicolumn{3}{|c|}{ Soil-specific calibration functions } \\
\hline & $r_{\mathrm{s}}(-)$ & $E_{\mathrm{RMS}}\left(\mathrm{m}^{3} \mathrm{~m}^{-3}\right)$ & $\operatorname{Bias}\left(\mathrm{m}^{3} \mathrm{~m}^{-3}\right)$ & & $r_{\mathrm{S}}(-)$ & $E_{\mathrm{RMS}}\left(\mathrm{m}^{3} \mathrm{~m}^{-3}\right)$ & $\operatorname{Bias}\left(\mathrm{m}^{3} \mathrm{~m}^{-3}\right)$ \\
\hline 1 & 0.95 & 0.0721 & -0.0643 & 42 & 0.95 & 0.0235 & 0 \\
\hline 7 & 0.98 & 0.0448 & -0.0357 & 53 & 0.98 & 0.0177 & 0 \\
\hline 10 & 0.99 & 0.0343 & -0.0237 & 56 & 0.99 & 0.0190 & 0 \\
\hline
\end{tabular}

\section{Results and discussion}

\subsection{Zone of influence}

The results in Fig. 6 show that in soil, the zone of influence ranges from 3 to $4 \mathrm{~cm}$ from the middle prong of the 5TM sensors. This is smaller than the propagation distance of $6 \mathrm{~cm}$ in air found by Cobos (2015) and larger than the propagation distance of $2.2 \mathrm{~cm}$ in deionized water found by Vaz et al. (2013). Open air does not affect the 5TM readings at the shallowest installation depth of $5 \mathrm{~cm}$ that is used in the Raam network. The results also indicate that soil moisture content does not affect the extent of the zone of influence.

\subsection{Calibration 5TM sensors}

The results of the calibration procedure in Fig. 7 show that the 5TM readings and gravimetric measurements correlate well. The relations between the 5TM readings and GVSMs can best be approximated by two-term power functions. This is preferred over polynomial functions because power functions keep increasing beyond the range of GVSMs obtained during the calibration procedure, which occurs in the field (further explained below). The power function between relative dielectric permittivity sensor readings and volumetric soil moisture content reads

$\theta_{\text {cal }}=A \cdot \varepsilon_{\mathrm{a}}^{B}+C$,

where $\theta_{\text {cal }}\left(\mathrm{m}^{3} \mathrm{~m}^{-3}\right)$ is the calibrated volumetric soil moisture content measurement, $\varepsilon_{\mathrm{a}}(-)$ is the measured relative dielectric permittivity, and $A, B$ and $C$ are calibration coefficients. The optimum calibration coefficients, listed in Table 4, are determined with the Matlab Curve Fitting Toolbox by non-linear least squares fitting.
Lab calibration has reduced $E_{\mathrm{RMS}}$ from $0.03-0.07$ to $0.02 \mathrm{~m}^{3} \mathrm{~m}^{-3}$ and has eliminated the bias between the 5TM readings and GVSMs (Table 5). The $E_{\mathrm{RMS}}$ values using the Topp function are comparable or slightly worse than the values obtained by other studies using Decagon sensors. The $E_{\mathrm{RMS}}$ values after the soil-specific calibration are comparable to the values obtained by other studies that performed a soil-specific calibration (Table 6).

\subsection{Data verification}

\subsubsection{Data series completeness}

The Raam network has generated data since April 2016. After 12 months of operations, the data series completeness is $96 \%$. Data gaps are caused by probes not being properly connected for a time and by the malfunctioning of sensors and loggers (specified in a readme file attached to the measurement data).

\subsubsection{Data series analysis}

We performed an initial data analysis of the behaviour and trends of soil moisture in the Raam. This includes an evaluation against the wilting point and saturated soil moisture content for the soils in which the stations are placed. The wilting point and saturated soil moisture content are estimated using the Staring series (Wösten et al., 2001), which provide the Van Genuchten parameters for soil water retention and soil hydraulic conductivity. These parameters can be used to estimate the soil moisture content for a specific pressure head using the Van Genuchten (1980) equation:

$\theta(h)=\theta_{\mathrm{r}}+\frac{\theta_{\mathrm{s}}-\theta_{\mathrm{r}}}{\left[1+(\alpha|h|)^{n}\right]^{1-1 / n}}$, 
Table 6. Accuracy metrics between GVSMs and readings by various Decagon sensors reported in previous studies.

\begin{tabular}{|c|c|c|c|c|}
\hline Study & Study area and soil type & Sensor & $\begin{array}{l}E_{\mathrm{RMS}} \text { with Topp function } \\
\left(\mathrm{m}^{3} \mathrm{~m}^{-3}\right)\end{array}$ & $\begin{array}{l}E_{\text {RMS with soil-specific }} \\
\text { calibration function } \\
\left(\mathrm{m}^{3} \mathrm{~m}^{-3}\right)\end{array}$ \\
\hline Bircher et al. (2012) & $\begin{array}{l}\text { Western Denmark: Podzol } \\
\text { sandy and loamy soils. }\end{array}$ & $5 \mathrm{TE}$ & $\begin{array}{l}\text { Agricultural land: } 0.030 \\
\text { Forest: } 0.026 \\
\text { Heath: } 0.022\end{array}$ & Not reported \\
\hline $\begin{array}{l}\text { Dente et al. (2009), Su et } \\
\text { al. (2011) }\end{array}$ & $\begin{array}{l}\text { Maqu, Tibetan Plateau: or- } \\
\text { ganic and silt loam soils. }\end{array}$ & EC-TM & 0.06 & 0.02 \\
\hline Dente et al. $(2011,2012)$ & $\begin{array}{l}\text { Twente, the Netherlands: } \\
\text { sand and loamy sand. }\end{array}$ & EC-TM & 0.054 & 0.023 \\
\hline Kizito et al. (2008) & $\begin{array}{l}\text { Oso Flaco, USA: sand. } \\
\text { Columbia, USA: silt loam. }\end{array}$ & $\mathrm{TE}$ & Not reported & $\begin{array}{l}\text { Combined: } 0.026 \\
\text { Sand: } 0.015 \\
\text { Silt loam: } 0.018\end{array}$ \\
\hline Matula et al. (2016) & $\begin{array}{l}\text { Prague, Czech Republic: } \\
\text { Haplic chernozem substrate } \\
\text { loess. }\end{array}$ & $\begin{array}{l}\text { EC-5 } \\
\text { TE }\end{array}$ & $\begin{array}{l}\text { EC-5: } 0.031 \\
\text { TE: } 0.029\end{array}$ & $\begin{array}{l}\text { EC-5: } 0.018 \\
\text { TE: } 0.023\end{array}$ \\
\hline Van der Velde et al. (2012) & $\begin{array}{l}\text { Naqu, Tibetan Plateau: } \\
\text { loamy sand with gravel } \\
\text { and high organic matter } \\
\text { content. }\end{array}$ & EC-10 & Not reported & 0.029 \\
\hline Vaz et al. (2013) & $\begin{array}{l}\text { Arizona, USA: sandy to } \\
\text { clayey soils. }\end{array}$ & $5 \mathrm{TE}$ & 0.040 & 0.026 \\
\hline Varble and Chávez (2011) & $\begin{array}{l}\text { Colorado, USA: see the } \\
\text { fourth and fifth column. }\end{array}$ & $5 \mathrm{TE}$ & $\begin{array}{l}\text { Sandy clay loam: } 0.022 \\
\text { Loamy sand: } 0.025 \\
\text { Clay loam: } 0.038\end{array}$ & $\begin{array}{l}\text { Sandy clay loam: } 0.021 \\
\text { Loamy sand: } 0.007 \\
\text { Clay loam: } 0.028\end{array}$ \\
\hline
\end{tabular}
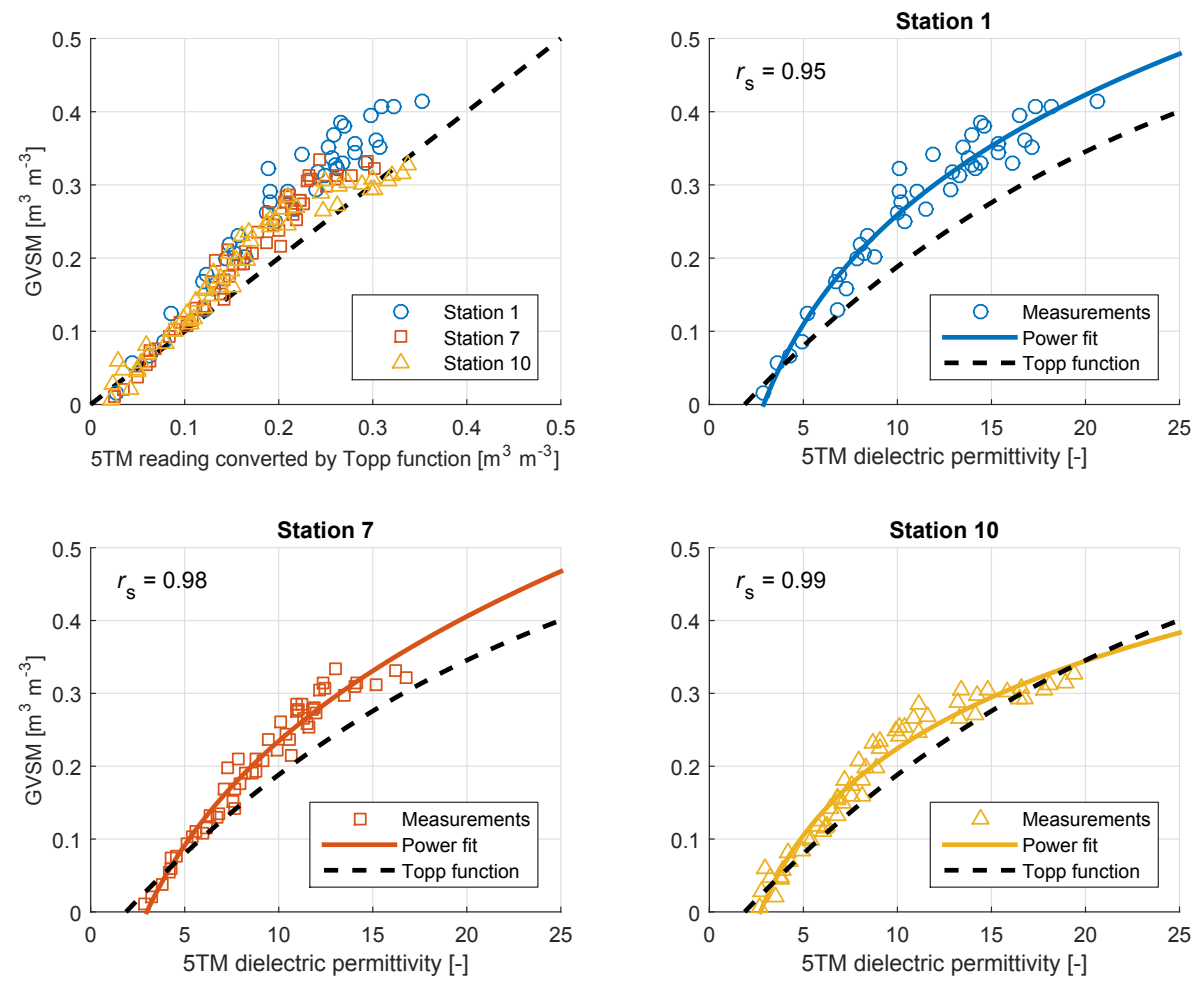

Figure 7. Decagon 5TM dielectric permittivity readings against GVSM, measured in the laboratory in soil from a selection of fields. The power fits are used as calibration functions for converting the relative dielectric permittivity measurements by 5TM sensors to volumetric soil moisture content. 

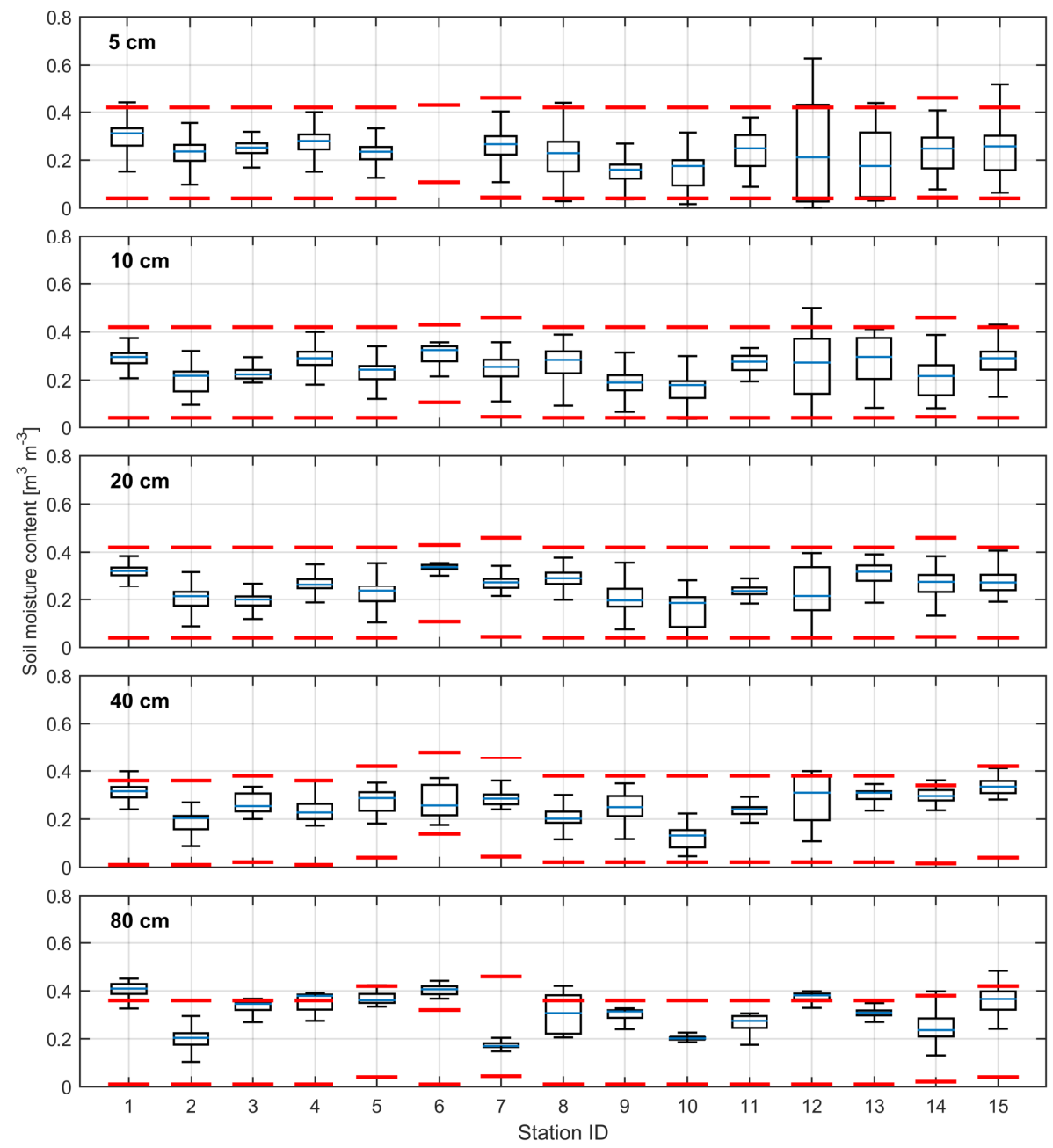

Figure 8. Box plots of the soil moisture measurements with theoretical wilting point and saturated soil moisture content from BOFEK2012 (red lines), for each depth measured (5 April 2016-4 April 2017). Note that the box plot of $5 \mathrm{~cm}$ depth of station 6 is not shown: these data are removed from the data set because of sensor malfunctioning.

where $h$ is the pressure head ( $\mathrm{cm}$ of water), $\theta(h)$ is the soil moisture content at pressure head $h\left(\mathrm{~m}^{3} \mathrm{~m}^{-3}\right), \theta_{\mathrm{r}}$ is the residual soil moisture content $\left(\mathrm{m}^{3} \mathrm{~m}^{-3}\right), \theta_{\mathrm{s}}$ is the saturated soil moisture content $\left(\mathrm{m}^{3} \mathrm{~m}^{-3}\right), \alpha$ is a scale parameter inversely proportional to the air entry value $\left(\mathrm{cm}^{-1}\right)$ and $n$ is a parameter related to the pore size distribution (-). BOFEK2012 provides the Staring series at the station locations (Wösten et al., 2013).

Figure 8 shows that, generally, the station measurements are within the range expected based on BOFEK2012. However, the measurements of stations 1,8 and 13 slightly exceed the saturated soil moisture content, and stations 12 and 15 exceed the saturated soil moisture content to a larger extent. Furthermore, the measurements at $80 \mathrm{~cm}$ depth at stations $1,4,6,8$ and 12 exceed the saturated soil moisture content for about $25 \%$ (station 8) to $100 \%$ (station 6) of the time. This may be explained by local soil variability that is not captured by BOFEK2012 and macroporosity that is not considered by BOFEK2012. As BOFEK2012 only considers soil matrix porosity, deviations may occur when additional cracks, biopores or other macropores exist.

Soil moisture measurements recorded in the field (Fig. 8) exceed the maximum GVSM obtained at saturated conditions in the laboratory (Fig. 7). Reasons may be the presence of roots and macropores in the field, which can never be reproduced with the disturbed soil samples used for the calibration. In the field, macropores may be present, which increase the saturated soil moisture content. Also the presence of large roots increases recorded water contents.

Figure 9 shows a time series plot of soil moisture measurements at station 1 for all measured depths, along with daily precipitation data of the Volkel weather station. The soil moisture series show a clear response to the precipitation events. The soil moisture at the upper layers shows larger dynamics than the soil moisture at deeper layers. The soil moisture at $80 \mathrm{~cm}$ is stable because it is controlled by the high 

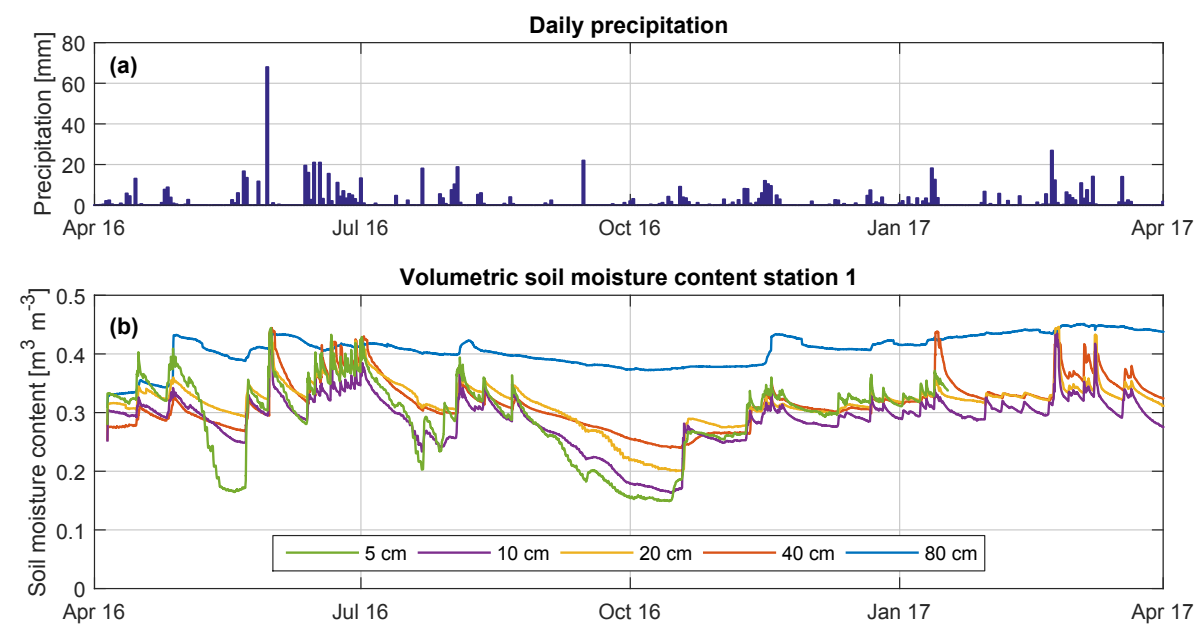

Figure 9. (a) Daily precipitation measured at Volkel weather station during the hydrological year 2016. (b) Soil moisture measurements at station 1 during the hydrological year 2016 at 5, 10, 20,40 and $80 \mathrm{~cm}$ depth.
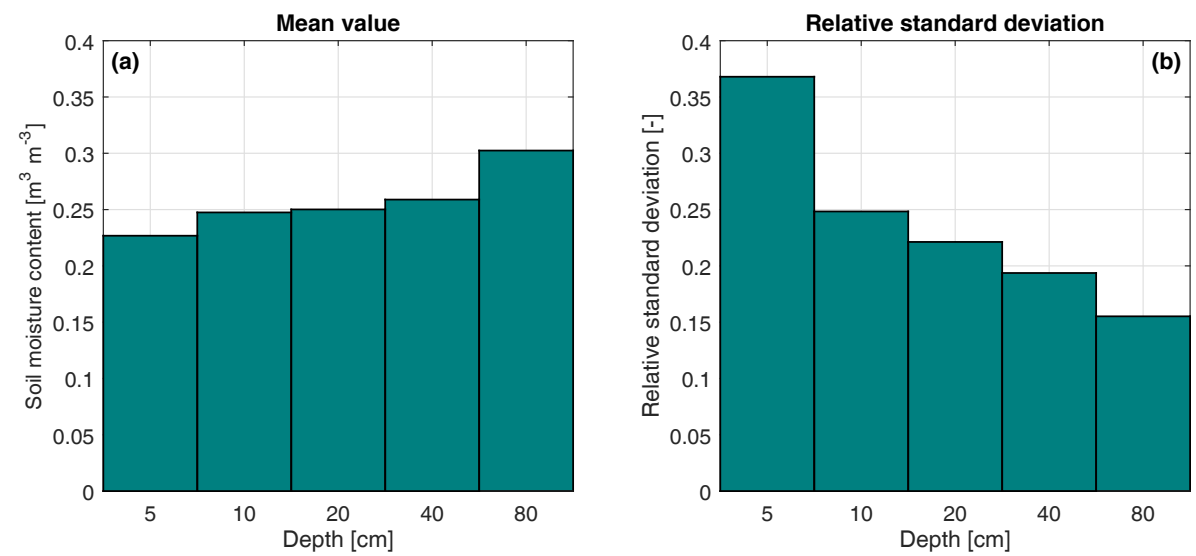

Figure 10. Soil moisture average and relative standard deviation (ratio of the standard deviation to the average soil moisture content), averaged over time (5 April 2016-4 April 2017) and over all stations for each depth measured.

phreatic groundwater level (GHG is $0.58 \mathrm{~m}$ below surface at the location of station 1; see Fig. 3).

Figure 10a shows that the average soil moisture content increases with depth from $0.23 \mathrm{~m}^{3} \mathrm{~m}^{-3}$ at $5 \mathrm{~cm}$ to $0.30 \mathrm{~m}^{3} \mathrm{~m}^{-3}$ at $80 \mathrm{~cm}$. Indeed, one can expect the topsoil to be drier than the deeper parts due to infiltration and evapotranspiration. Figure 10b shows the relative standard deviation, which is defined as the ratio of the standard deviation of the soil moisture measurements to the average soil moisture content, for each depth averaged over time and over all stations. A higher relative standard deviation indicates a larger variability in soil moisture. Figure $10 \mathrm{~b}$ indicates a decreasing variability in soil moisture with increasing depth, which was also visible for station 1 in Fig. 9. The upper layers are mainly controlled by precipitation and evapotranspiration, which are variable in time. The deeper layers are mainly controlled by the generally high phreatic groundwater levels (Fig. 3), which provide a continuous source of water by capillary rise.
We explored the influence of various factors on the dynamics of soil moisture. Figure 11a confirms our expectation that sandy soils have lower and more dynamic soil moisture contents than loamy/clayey soils. Figure $11 \mathrm{~b}$ shows that locations with deep groundwater levels $(>1 \mathrm{~m})$ are drier than locations with shallow groundwater levels $(<1 \mathrm{~m})$. The situation of shallow groundwater levels applies to the stations 1 , $6,8,11,12,13$ and 15 , based on groundwater level measurements by Waterschap Aa en Maas. Figure 11c shows that, in general, the soil moisture content of corn fields is largest. Also, in the winter period of 2016/2017 grasslands tend to be wetter than fields with sugar beets and onions. The observed dynamics of soil moisture on the catchment scale are as expected. However, local differences in surface elevation, soil composition and land cover play an important role in localscale variation. Over time, changes in land cover and macroporosity and temperature effects (Sect. 4.3.3) introduce uncertainties. 

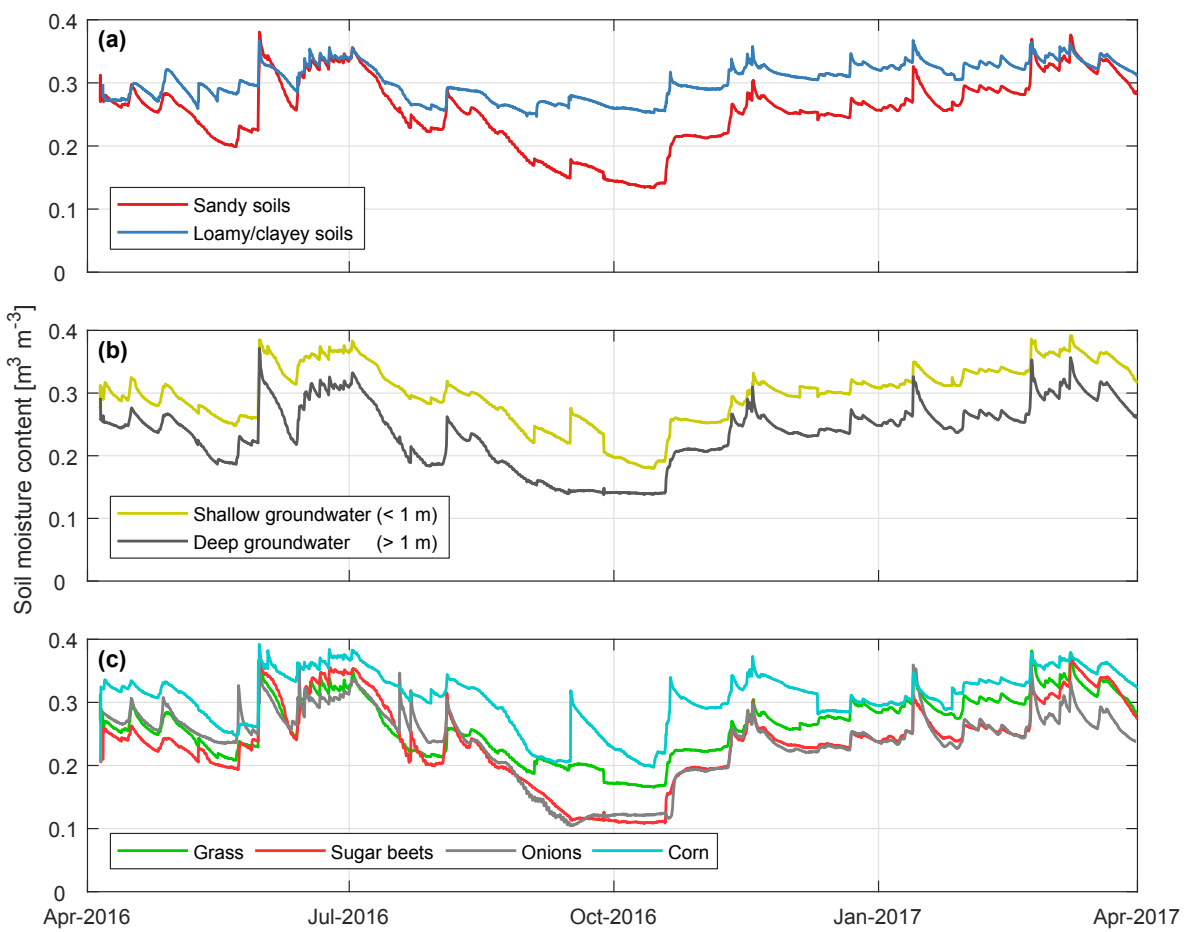

Figure 11. Influence of (a) soil type (Table 2), (b) groundwater depth (based on groundwater level measurements by Waterschap Aa en Maas) and (c) vegetation type (Table 3) on the soil moisture dynamics at $20 \mathrm{~cm}$ depth.
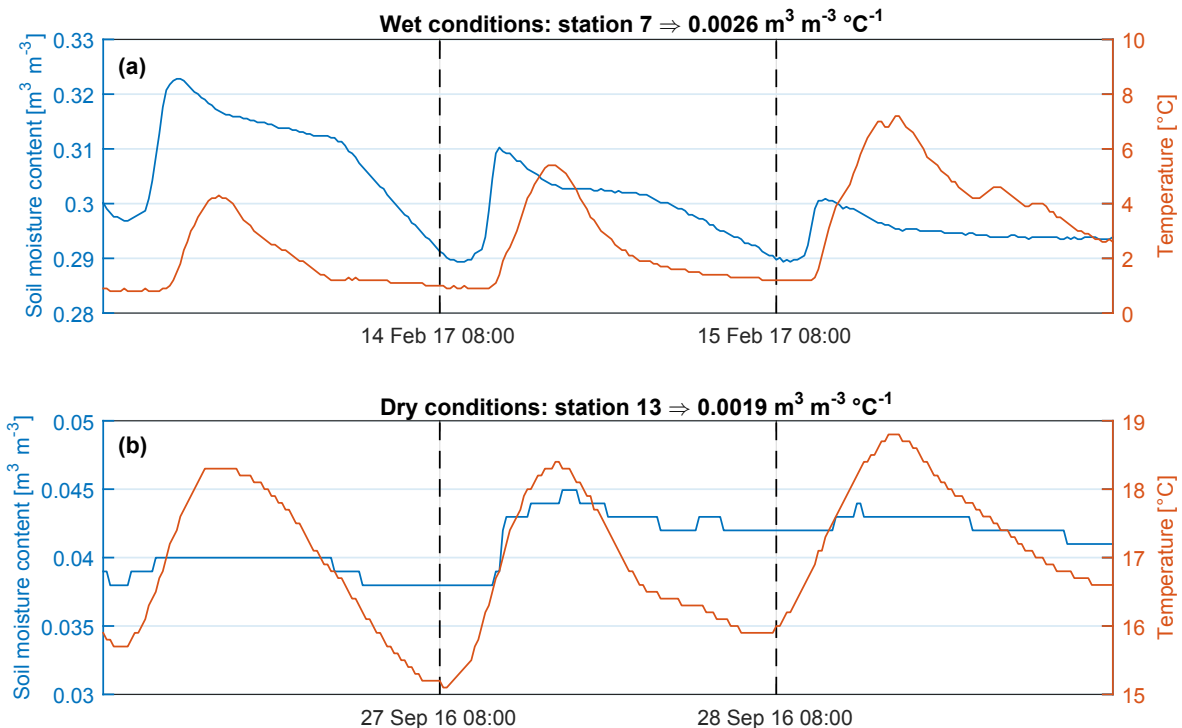

Figure 12. Largest sensitivities of soil moisture (blue line, left $y$ axis) to temperature variation (red line, right $y$ axis) in (a) wet conditions and (b) dry conditions.

\subsubsection{Effect of temperature}

The soil moisture measurements at 5, 10 and $20 \mathrm{~cm}$ depth show diurnal variations at all stations. Potential hydrological causes are the presence of dew and adsorption of water vapour by the soil, which cause an increase in soil moisture content during the night and morning (Agam and Berliner, 2006; Kosmas et al., 1998). Alternatively, the soil moisture sensors might be sensitive to temperature. A number of studies found that the dielectric permittivity readings of soil moisture sensors are affected by soil temperature, varying from -0.002 to $0.004 \mathrm{~m}^{3} \mathrm{~m}^{-3{ }^{\circ}} \mathrm{C}^{-1}$ (Bogena et al., 
2007; Kizito et al., 2008; Rosenbaum et al., 2011; Verhoef et al., 2006). Figure 12 shows the largest soil-moisture-totemperature sensitivities measured at $5 \mathrm{~cm}$ depth, between 08:00 CET at day 1 and 08:00 CET at day 2, under the conditions of no precipitation on the day itself and the preceding 2 days, a maximum temperature difference between start and end time of $1.0^{\circ} \mathrm{C}$, and a maximum soil moisture difference between start and end time of $0.005 \mathrm{~m}^{3} \mathrm{~m}^{-3}$. The soil moisture series are linearly detrended, assuming constant drainage and evaporation over the period of investigation (Cobos and Campbell, 2016). Then, we found the soilmoisture-to-temperature sensitivities by applying a linear fit between the detrended soil moisture series and the soil temperature series. At station 7 in wet conditions (Fig. 12a), there is a lag between the trends of soil moisture and temperature. This suggests that a soil hydrological process caused the diurnal variation in soil moisture, such as the addition of water by dew. At station 13 in dry conditions (Fig. 12b), there is probably a direct effect of temperature on the soil moisture signal. Over all stations and all diurnal cycles satisfying the conditions introduced above, the average absolute sensitivity of soil moisture to temperature is $0.0006 \mathrm{~m}^{3} \mathrm{~m}^{-3^{\circ}} \mathrm{C}^{-1}$. The difference between the minimum and maximum daily average soil temperature at $5 \mathrm{~cm}$ over the measurement period 5 April 2016 to 4 April 2017 is 19 to $28^{\circ} \mathrm{C}$. This translates into an effect of 0.011 to $0.017 \mathrm{~m}^{3} \mathrm{~m}^{-3}$ on the soil moisture measurements by seasonal temperature variation. We consider this a small effect compared to local variations and other measurement uncertainties, and since there might also be a soil hydrological cause, we do not correct for the effect of temperature variation.

The freezing of soils has a distinct effect on soil moisture measurements. When soils are frozen, the free water content decreases and this affects the bulk dielectric permittivity. These measurements do, however, give information about the free and frozen water contents. Together with the simultaneous soil temperature measurements, this could support research on the freezing of soils. However, the affected measurements are not usable as soil moisture measurements, so users of the soil moisture data are recommended to remove these from the measurement series.

\section{Data availability}

The soil moisture and temperature data are available at the 4TU.ResearchData data centre at https://doi.org/10.4121/uuid:dc364e97-d44a-403f-82a7-

121902deeb56 (Benninga et al., 2017). The data are found under the "DATA" header. The data set currently covers the period between 5 April 2016 and 4 April 2017. New data will be added to the data collection at https://doi.org/10.4121/uuid:2411bbb8-2161-4f31-985f7b65b8448bc9 (Benninga et al., 2018). Data collection will continue until at least October 2019. The data are stored in CSV files. A readme file describes the structure of the CSVs, contact information and metadata. Also included is a file containing information about additional data sets available for the Raam catchment (elevation, soil physical, land cover, groundwater level and meteorological data). Due acknowledgment in any publication or presentation arising from the use of these data is required.

\section{Conclusions}

The Raam soil moisture and temperature profile monitoring network contains 15 stations distributed over the Raam region. In total, 12 stations are located within the Raam catchment (catchment area of $223 \mathrm{~km}^{2}$ ), and 5 of these stations are located within a closed sub-catchment of the Raam catchment (catchment area of $41 \mathrm{~km}^{2}$ ). The stations consist of 5TM sensors installed at 5, 10, 20, 40 and $80 \mathrm{~cm}$ depth. The measurements at $5 \mathrm{~cm}$ depth provide a reference for surface soil moisture estimations from earth observations, and the measurements at deeper layers enable the investigation of soil hydrological processes throughout the unsaturated zone. The experiment on the sensor's zone of influence shows that the sensor integrates a soil volume of 3 to $4 \mathrm{~cm}$ above and below the sensor's middle prong, so the installation depth of $5 \mathrm{~cm}$ is required to avoid effects of the open air. Soil-specific calibration functions for the 5TM sensors that have been developed under laboratory conditions lead to an accuracy of $0.02 \mathrm{~m}^{3} \mathrm{~m}^{-3}$, which is lower than the accuracy range of $0.03-$ $0.07 \mathrm{~m}^{3} \mathrm{~m}^{-3}$ when applying the Topp function. Analysis of the first year of data shows that the station measurements are generally within the range expected based on the classified soil units and associated soil physical characteristics from the soil map of the Netherlands (BOFEK2012). Exceedance of the expected saturated soil moisture content occurs at stations $1,4,6,8,12,13$ and 15 , which could be the effect of local soil variability not captured by BOFEK2012 and macroporosity not considered by BOFEK2012. The measurements show expected soil moisture trends across the soil profile, with the average soil moisture increasing and the soil moisture variability decreasing with depth. The measurements confirm that sandy soils have lower and more dynamic soil moisture contents than loamy/clayey soils and locations with deep groundwater levels are drier than locations with shallow groundwater levels. Among the stations of the Raam network, on average, corn fields and grasslands are wetter than fields with sugar beets and onions.

The Raam soil moisture monitoring network and the mentioned additional data sets provide a valuable and ongoing data set for investigating water management applications, for the calibration and validation of soil moisture estimations from earth observations on a coarse scale and a field scale, for the understanding of processes affected by soil moisture in the unsaturated zone, and for the assessment of land pro- 
cess models. Stations 1 to 7,10 and 12 to 15 can also be used for modelling the behaviour of the Raam catchment.

Competing interests. The authors declare that they have no conflict of interest.

Acknowledgements. This work is part of the research programme OWAS1S (Optimizing Water Availability with Sentinel-1 Satellites) with project number 13871 which is partly financed by the Netherlands Organisation for Scientific Research (NWO). The regional water management authority Waterschap Aa en Maas contributed to the installation and maintenance of the network, and we thank Arjan Peters and Marijn van Helvert in particular. We also thank the field owners for their cooperation in granting access. Furthermore, we thank Caroline Lievens (University of Twente, Faculty of Geo-Information Science and Earth Observation) for her help with the soil texture analysis in the laboratory.

Edited by: David Carlson

Reviewed by: two anonymous referees

\section{References}

Actueel Hoogtebestand Nederland: Actueel Hoogtebestand Nederland, [online] available at: www.ahn.nl, last access: 1 December 2016.

Agam, N. and Berliner, P. R.: Dew formation and water vapor adsorption in semi-arid environments - A review, J. Arid Environ., 65, 572-590, https://doi.org/10.1016/j.jaridenv.2005.09.004, 2006.

Ahmad, M., Bastiaanssen, W. G. M., and Feddes, R. A.: Sustainable use of groundwater for irrigation: a numerical analysis of the subsoil water fluxes, Irrig. Drain., 51, 227-241, https://doi.org/10.1002/ird.59, 2002.

Albergel, C., Rüdiger, C., Pellarin, T., Calvet, J.-C., Fritz, N., Froissard, F., Suquia, D., Petitpa, A., Piguet, B., and Martin, E.: From near-surface to root-zone soil moisture using an exponential filter: an assessment of the method based on in-situ observations and model simulations, Hydrol. Earth Syst. Sci., 12, 1323-1337, https://doi.org/10.5194/hess-12-1323-2008, 2008.

Albergel, C., de Rosnay, P., Balsamo, G., Isaksen, L., and MuñozSabater, J.: Soil Moisture Analyses at ECMWF: Evaluation Using Global Ground-Based In Situ Observations, J. Hydrometeorol., 13, 1442-1460, https://doi.org/10.1175/JHM-D-11-0107.1, 2012.

Batey, T.: Soil compaction and soil management - a review, Soil Use Manag., 25, 335-345, https://doi.org/10.1111/j.14752743.2009.00236.x, 2009.

Beck, H. E., De Jeu, R. A. M., Schellekens, J., Van Dijk, A. I. J. M., and Bruijnzeel, L. A.: Improving Curve Number Based Storm Runoff Estimates Using Soil Moisture Proxies, IEEE J. Sel. Top. Appl. Earth Obs. Remote Sens., 2, 250-259, https://doi.org/10.1109/JSTARS.2009.2031227, 2009.

Benninga, H. F., Carranza, C. D. U., Pezij, M., Van der Ploeg, M. J., Augustijn, D. C. M., and Van der Velde, R.: Regional soil moisture monitoring network in the
Raam catchment in the Netherlands - 2016-04/2017-04, https://doi.org/10.4121/uuid:dc364e97-d44a-403f-82a7-

121902deeb56, last access: 16 December 2017.

Benninga, H. F., Carranza, C. D. U., Pezij, M., Van der Ploeg, M. J., Augustijn, D. C. M., and Van der Velde, R.: Regional soil moisture monitoring network in the Raam catchment in the Netherlands, https://doi.org/10.4121/uuid:2411bbb8-2161-4f31985f-7b65b8448bc9, last access: 2 January 2018.

Beven, K., Cloke, H., Pappenberger, F., Lamb, R., and Hunter, N.: Hyperresolution information and hyperresolution ignorance in modelling the hydrology of the land surface, Sci. China Earth Sci., 58, 25-35, https://doi.org/10.1007/s11430-014-50034, 2015.

Bircher, S., Skou, N., Jensen, K. H., Walker, J. P., and Rasmussen, L.: A soil moisture and temperature network for SMOS validation in Western Denmark, Hydrol. Earth Syst. Sci., 16, 14451463, https://doi.org/10.5194/hess-16-1445-2012, 2012.

Blume, H.-P. and Leinweber, P.: Plaggen Soils: landscape history, properties, and classification, J. Plant Nutr. Soil Sci., 167, 319327, https://doi.org/10.1002/jpln.200420905, 2004.

Bogena, H. R., Huisman, J. A., Oberdörster, C., and Vereecken, H.: Evaluation of a low-cost soil water content sensor for wireless network applications, J. Hydrol., 344, 32-42, https://doi.org/10.1016/j.jhydrol.2007.06.032, 2007.

Bogena, H. R., Herbst, M., Huisman, J. A., Rosenbaum, U., Weuthen, A., and Vereecken, H.: Potential of Wireless Sensor Networks for Measuring Soil Water Content Variability, Vadose Zo. J., 9, 1002-1013, https://doi.org/10.2136/vzj2009.0173, 2010.

Bosch, D. D., Sheridan, J. M., and Marshall, L. K.: Precipitation, soil moisture, and climate database, Little River Experimental Watershed, Georgia, United States, Water Resour. Res., 43, W09472, https://doi.org/10.1029/2006WR005834, 2007.

Burgin, M. S., Colliander, A., Njoku, E. G., Chan, S. K., Cabot, F., Kerr, Y. H., Bindlish, R., Jackson, T. J., Entekhabi, D., and Yueh, S. H.: A Comparative Study of the SMAP Passive Soil Moisture Product With Existing Satellite-Based Soil Moisture Products, IEEE Trans. Geosci. Remote Sens., 55, 2959-2971, https://doi.org/10.1109/TGRS.2017.2656859, 2017.

Calvet, J.-C., Fritz, N., Froissard, F., Suquia, D., Petitpa, A., and Piguet, B.: In situ soil moisture observations for the CAL/VAL of SMOS: The SMOSMANIA network, in 2007 IEEE International Geoscience and Remote Sensing Symposium, 1196-1199, IEEE, Barcelona, Spain, 2007.

Carrão, H., Russo, S., Sepulcre-Canto, G., and Barbosa, P.: An empirical standardized soil moisture index for agricultural drought assessment from remotely sensed data, Int. J. Appl. Earth Obs. Geoinf., 48, 74-84, https://doi.org/10.1016/j.jag.2015.06.011, 2016.

Chan, S. K., Bindlish, R., O’Neill, P. E., Njoku, E., Jackson, T., Colliander, A., Chen, F., Burgin, M., Dunbar, S., Piepmeier, J., Yueh, S., Entekhabi, D., Cosh, M. H., Caldwell, T., Walker, J., Wu, X., Berg, A., Rowlandson, T., Pacheco, A., McNairn, H., Thibeault, M., Martinez-Fernandez, J., Gonzalez-Zamora, A., Seyfried, M., Bosch, D., Starks, P., Goodrich, D., Prueger, J., Palecki, M., Small, E. E., Zreda, M., Calvet, J. C., Crow, W. T., and Kerr, Y.: Assessment of the SMAP Passive Soil Moisture Product, IEEE T. Geosci. Remote Sens., 54, 4994-5007, https://doi.org/10.1109/TGRS.2016.2561938, 2016. 
Chen, F., Crow, W. T., Starks, P. J., and Moriasi, D. N.: Improving hydrologic predictions of a catchment model via assimilation of surface soil moisture, Adv. Water Resour., 34, 526-536, https://doi.org/10.1016/j.advwatres.2011.01.011, 2011.

Cobos, D.: Application Note: Measurement Volume of Decagon Volumetric Water Content Sensors, Pullman, Washington, USA., available at: http://manuals.decagon.com/Application\%20Notes/ 14955_VWC\%20Sensor\%20Measurement\%20Volumes_Web. pdf (last access: 13 November 2017), 2015.

Cobos, D. and Campbell, C.: Application Note: Correcting Temperature Sensitivity of ECH2O Soil Moisture Sensors, Pullman, Washington, USA, available at: http://www.onsetcomp.com/ files/15923-C\%20Correcting\%20Temperature\%20Sensitivity\% 20of\%20ECH2O\%20Soil\%20Moisture\%20Sensors.pdf (last access: 13 November 2017), 2016.

Cobos, D. R. and Chambers, C.: Application Note: Calibrating ECH2O Soil Moisture Sensors, Pullman, Washington, USA, available at: http://manuals.decagon.com/Application\%20Notes/ 13393_Calibrating\%20ECH2O\%20Probes_Print.pdf (last access: 13 November 2017), 2010.

Colliander, A., Jackson, T. J., Bindlish, R., Chan, S., Das, N., Kim, S. B., Cosh, M. H., Dunbar, R. S., Dang, L., Pashaian, L., Asanuma, J., Aida, K., Berg, A., Rowlandson, T., Bosch, D., Caldwell, T., Caylor, K., Goodrich, D., al Jassar, H., Lopez-Baeza, E., Martínez-Fernández, J., González-Zamora, A., Livingston, S., McNairn, H., Pacheco, A., Moghaddam, M., Montzka, C., Notarnicola, C., Niedrist, G., Pellarin, T., Prueger, J., Pulliainen, J., Rautiainen, K., Ramos, J., Seyfried, M., Starks, P., Su, Z., Zeng, Y., Van der Velde, R., Thibeault, M., Dorigo, W., Vreugdenhil, M., Walker, J. P., Wu, X., Monerris, A., O’Neill, P. E., Entekhabi, D., Njoku, E. G., and Yueh, S.: Validation of SMAP surface soil moisture products with core validation sites, Remote Sens. Environ., 191, 215-231, https://doi.org/10.1016/j.rse.2017.01.021, 2017.

Cosh, M. H., Jackson, T. J., Starks, P., and Heathman, G.: Temporal stability of surface soil moisture in the Little Washita River watershed and its applications in satellite soil moisture product validation, J. Hydrol., 323, 168-177, https://doi.org/10.1016/j.jhydrol.2005.08.020, 2006.

Crow, W. T., Berg, A. A., Cosh, M. H., Loew, A., Mohanty, B. P., Panciera, R., De Rosnay, P., Ryu, D., and Walker, J. P.: Upscaling sparse ground-based soil moisture observations for the validation of coarse-resolution satellite soil moisture products, Rev. Geophys., 50, RG2002, https://doi.org/10.1029/2011RG000372, 2012.

Das, N. N. and Mohanty, B. P.: Root Zone Soil Moisture Assessment Using Remote Sensing and Vadose Zone Modeling, Vadose Zo. J., 5, 296-307, https://doi.org/10.2136/vzj2005.0033, 2006.

Das, N. N., Entekhabi, D., Njoku, E. G., Shi, J. J. C., Johnson, J. T., and Colliander, A.: Tests of the SMAP Combined Radar and Radiometer Algorithm Using Airborne Field Campaign Observations and Simulated Data, IEEE T. Geosci. Remote Sens., 52, 2018-2028, https://doi.org/10.1109/TGRS.2013.2257605, 2014.

Davies, B. E.: Loss-on-Ignition as an Estimate of Soil Organic Matter, Soil Sci. Soc. Am. J., 38, 150-151, https://doi.org/10.2136/sssaj1974.03615995003800010046x, 1974.

Decagon Devices: 5TM Water Content and Temperature Sensors, Pullman, Washington, USA, available at: http://manuals.
decagon.com/Manuals/13441_5TM_Web.pdf (last access: 13 November 2017), 2016.

De Lange, W. J., Prinsen, G. F., Hoogewoud, J. C., Veldhuizen, A. A., Verkaik, J., Oude Essink, G. H. P., Van Walsum, P. E. V, Delsman, J. R., Hunink, J. C., Massop, H. T. L., and Kroon, T.: An operational, multi-scale, multi-model system for consensus-based, integrated water management and policy analysis: The Netherlands Hydrological Instrument, Environ. Model. Softw., 59, 98 108, https://doi.org/10.1016/j.envsoft.2014.05.009, 2014.

Dente, L., Vekerdy, Z., Su, Z., and Wen, J.: Continuous in situ soil moisture measurements at Maqu site, Strasbourg, France., available at: ftp://ftp.itc.nl/ext/smapcalval/for\%20Aquarius\% 20CalVal/Maqu/ReportMaquMonitoringNetwork.pdf (last access: 13 November 2017), 2009.

Dente, L., Vekerdy, Z., Su, Z., and Ucer, M.: Twente soil moisture and soil temperature monitoring network, Enschede, the Netherlands., available at: https://www.itc.nl/library/papers_2011/scie/ dente_twe.pdf (last access: 13 November 2017), 2011.

Dente, L., Su, Z., and Wen, J.: Validation of SMOS soil moisture products over the Maqu and Twente Regions, Sensors, 12, 99659986, https://doi.org/10.3390/s120809965, 2012.

Dirmeyer, P. A., Gao, X., Zhao, M., Guo, Z., Oki, T., and Hanasaki, N.: GSWP-2: Multimodel Analysis and Implications for Our Perception of the Land Surface, B. Am. Meteorol. Soc., 87, 13811397, https://doi.org/10.1175/BAMS-87-10-1381, 2006.

Dorigo, W. A., Wagner, W., Hohensinn, R., Hahn, S., Paulik, C., Xaver, A., Gruber, A., Drusch, M., Mecklenburg, S., van Oevelen, P., Robock, A., and Jackson, T.: The International Soil Moisture Network: a data hosting facility for global in situ soil moisture measurements, Hydrol. Earth Syst. Sci., 15, 1675-1698, https://doi.org/10.5194/hess-15-1675-2011, 2011.

Escorihuela, M. J., Chanzy, A., Wigneron, J. P., and Kerr, Y. H.: Effective soil moisture sampling depth of L-band radiometry: A case study, Remote Sens. Environ., 114, 995-1001, https://doi.org/10.1016/j.rse.2009.12.011, 2010.

Feddes, R. A., Kowalik, P. J., and Zaradny, H.: Simulation of field water use and crop yield, Centre for Agricultural Publishing and Documentation, Wageningen, the Netherlands, 1978.

Ford, T. W., Harris, E., and Quiring, S. M.: Estimating root zone soil moisture using near-surface observations from SMOS, Hydrol. Earth Syst. Sci., 18, 139-154, https://doi.org/10.5194/hess18-139-2014, 2014.

Global Climate Observing System: The Global Observing System for Climate: Implementation Needs, available at: https://unfccc.int/files/science/workstreams/systematic_ observation/application/pdf/gcos_ip_10oct2016.pdf (last access: 13 November 2017), 2010.

Hamza, M. A. and Anderson, W. K.: Soil compaction in cropping systems: A review of the nature, causes and possible solutions, Soil Tillage Res., 82, 121-145, https://doi.org/10.1016/j.still.2004.08.009, 2005.

Hartemink, A. E. and De Bakker, H.: Classification Systems: Netherlands, in: Encyclopedia of Soil Science, edited by: Lal, R., 265-268, Taylor \& Francis Group, Boca Raton, Florida, USA, 2006.

Hoogsteen, M. J. J., Lantinga, E. A., Bakker, E. J., Groot, J. C. J., and Tittonell, P. A.: Estimating soil organic carbon through loss on ignition: effects of ignition conditions 
and structural water loss, Eur. J. Soil Sci., 66, 320-328, https://doi.org/10.1111/ejss.12224, 2015.

Houser, P. R., De Lannoy, G. J. M., and Walker, J. P.: Hydrologic Data Assimilation, in: Approaches to Managing Disaster - Assessing Hazards, Emergencies and Disaster Impacts, edited by: Tiefenbacher, J., 41-64, InTech., 2012.

Kerr, Y. H., Waldteufel, P., Wigneron, J. P., Delwart, S., Cabot, F., Boutin, J., Escorihuela, M. J., Font, J., Reul, N., Gruhier, C., Juglea, S. E., Drinkwater, M. R., Hahne, A., Martin-Neira, M., and Mecklenburg, S.: The SMOS Mission: New Tool for Monitoring Key Elements of the Global Water Cycle, Proc. IEEE, 98, 666687, https://doi.org/10.1109/jproc.2010.2043032, 2010.

Kerr, Y. H., Al-Yaari, A., Rodriguez-Fernandez, N., Parrens, M., Molero, B., Leroux, D., Bircher, S., Mahmoodi, A., Mialon, A., Richaume, P., Delwart, S., Al Bitar, A., Pellarin, T., Bindlish, R., Jackson, T. J., Rüdiger, C., Waldteufel, P., Mecklenburg, S., and Wigneron, J. P.: Overview of SMOS performance in terms of global soil moisture monitoring after six years in operation, Remote Sens. Environ., 180, 40-63, https://doi.org/10.1016/j.rse.2016.02.042, 2016.

Kizito, F., Campbell, C. S., Campbell, G. S., Cobos, D. R., Teare, B. L., Carter, B., and Hopmans, J. W.: Frequency, electrical conductivity and temperature analysis of a low-cost capacitance soil moisture sensor, J. Hydrol., 352, 367-378, https://doi.org/10.1016/j.jhydrol.2008.01.021, 2008.

Kornelsen, K. C. and Coulibaly, P.: Advances in soil moisture retrieval from synthetic aperture radar and hydrological applications, J. Hydrol., 476, 460-489, https://doi.org/10.1016/j.jhydrol.2012.10.044, 2013.

Kosmas, C., Danalatos, N. G., Poesen, J., and van Wesemael, B.: The effect of water vapour adsorption on soil moisture content under Mediterranean climatic conditions, Agric. Water Manag., 36, 157-168, https://doi.org/10.1016/S0378-3774(97)00050-4, 1998.

Martínez-Fernández, J. and Ceballos, A.: Mean soil moisture estimation using temporal stability analysis, J. Hydrol., 312, 28-38, https://doi.org/10.1016/j.jhydrol.2005.02.007, 2005.

Massari, C., Brocca, L., Moramarco, T., Tramblay, Y., and Didon Lescot, J. F.: Potential of soil moisture observations in flood modelling: Estimating initial conditions and correcting rainfall, Adv. Water Resour., 74, 44-53, https://doi.org/10.1016/j.advwatres.2014.08.004, 2014.

Matula, S., Bát'ková, K., and Legese, W. L.: Laboratory Performance of Five Selected Soil Moisture Sensors Applying Factory and Own Calibration Equations for Two Soil Media of Different Bulk Density and Salinity Levels, Sensors, 16, 1912, https://doi.org/10.3390/s16111912, 2016.

Nolan, M. and Fatland, D. R.: Penetration depth as a DInSAR observable and proxy for soil moisture, IEEE T. Geosci. Remote Sens., 41, 532-537, https://doi.org/10.1109/TGRS.2003.809931, 2003.

Pathe, C., Wagner, W., Sabel, D., Doubkova, M., and Basara, J. B.: Using ENVISAT ASAR Global Mode Data for Surface Soil Moisture Retrieval Over Oklahoma, USA, IEEE T. Geosci. Remote Sens., 47, 468-480, https://doi.org/10.1109/TGRS.2008.2004711, 2009.

Petropoulos, G. P., Ireland, G., and Barrett, B.: Surface soil moisture retrievals from remote sensing: Current status, products \& future trends, Phys. Chem. Earth, Parts A/B/C, 83-84, 36-56, https://doi.org/10.1016/j.pce.2015.02.009, 2015.

Reichle, R. H.: Data assimilation methods in the Earth sciences, Adv. Water Resour., 31, 1411-1418, https://doi.org/10.1016/j.advwatres.2008.01.001, 2008.

Rondinelli, W. J., Hornbuckle, B. K., Patton, J. C., Cosh, M. H., Walker, V. A., Carr, B. D., and Logsdon, S. D.: Different Rates of Soil Drying After Rainfall are Observed by the SMOS Satellite and the South Fork In Situ Soil Moisture Network, J. Hydrometeorol., 16, 889-903, https://doi.org/10.1175/JHM-D-14-0137.1, 2015.

Rosenbaum, U., Huisman, J. A., Weuthen, A., Vereecken, H., and Bogena, H. R.: Sensor-to-Sensor Variability of the ECH2O EC5, TE, and 5TE Sensors in Dielectric Liquids, Vadose Zo. J., 9, 181-186, https://doi.org/10.2136/vzj2009.0036, 2010.

Rosenbaum, U., Huisman, J. A., Vrba, J., Vereecken, H., and Bogena, H. R.: Correction of Temperature and Electrical Conductivity Effects on Dielectric Permittivity Measurements with ECH2O Sensors, Vadose Zo. J., 10, 582-593, https://doi.org/10.2136/vzj2010.0083, 2011.

Royal Netherlands Meteorological Institute (KNMI): Klimatologie - Metingen en waarnemingen, available at: http://www.knmi.nl/ nederland-nu/klimatologie-metingen-en-waarnemingen, last access: 17 May 2017.

Sakaki, T., Limsuwat, A., Smits, K. M., and Illangasekare, T. H.: Empirical two-point $\alpha$-mixing model for calibrating the ECH2O EC-5 soil moisture sensor in sands, Water Resour. Res., 44, W00D08, https://doi.org/10.1029/2008WR006870, 2008.

Schlumberger Water Services: Diver Manual, 36, available at: http://www.swstechnology.com/novametrix/pdfs/equipment/ Diver_manuals/Diver_Product_Manual_en.pdf (last access: 13 November 2017), 2014.

Schwilch, G., Bernet, L., Fleskens, L., Giannakis, E., Leventon, J., Marañón, T., Mills, J., Short, C., Stolte, J., Van Delden, H., and Verzandvoort, S.: Operationalizing ecosystem services for the mitigation of soil threats: A proposed framework, Ecol. Indic., 67, 568-597, https://doi.org/10.1016/j.ecolind.2016.03.016, 2016.

Seneviratne, S. I., Corti, T., Davin, E. L., Hirschi, M., Jaeger, E. B., Lehner, I., Orlowsky, B., and Teuling, A. J.: Investigating soil moisture-climate interactions in a changing climate: A review, Earth-Science Rev., 99, 125-161, https://doi.org/10.1016/j.earscirev.2010.02.004, 2010.

Shellito, P. J., Small, E. E., Colliander, A., Bindlish, R., Cosh, M. H., Berg, A. A., Bosch, D. D., Caldwell, T. G., Goodrich, D. C., Mcnairn, H., Prueger, J. H., Starks, P. J., Van der Velde, R., and Walker, J. P.: SMAP soil moisture drying more rapid than observed in situ following rainfall events, Geophys. Res. Lett., 43, 8068-8075, https://doi.org/10.1002/2016GL069946, 2016.

Smith, A. B., Walker, J. P., Western, A. W., Young, R. I., Ellett, K. M., Pipunic, R. C., Grayson, R. B., Siriwardena, L., Chiew, F. H. S., and Richter, H.: The Murrumbidgee soil moisture monitoring network data set, Water Resour. Res., 48, W07701, https://doi.org/10.1029/2012WR011976, 2012.

Srivastava, P. K., Han, D., Rico-Ramirez, M. A., O’Neill, P., Islam, T., Gupta, M., and Dai, Q.: Performance evaluation of WRF-Noah Land surface model estimated soil moisture for hydrological application: Synergistic evaluation us- 
ing SMOS retrieved soil moisture, J. Hydrol., 529, 200-212, https://doi.org/10.1016/j.jhydrol.2015.07.041, 2015.

Starr, J. L. and Paltineanu, I. C.: Methods for Measurement of Soil Water Content: Capacitance Devices, in: Methods of Soil Analysis: Part 4 - Physical Methods, edited by: Dane, J. H. and Topp, G. C., 463-474, Soil Science Society of America Book Series, Madison, Wisconsin, USA, 2002.

Steele-Dunne, S. C., Friesen, J., and Van de Giesen, N.: Using Diurnal Variation in Backscatter to Detect Vegetation Water Stress, IEEE T. Geosci. Remote Sens., 50, 2618-2629, https://doi.org/10.1109/TGRS.2012.2194156, 2012.

Su, Z., Wen, J., Dente, L., van der Velde, R., Wang, L., Ma, Y., Yang, K., and Hu, Z.: The Tibetan Plateau observatory of plateau scale soil moisture and soil temperature (TibetObs) for quantifying uncertainties in coarse resolution satellite and model products, Hydrol. Earth Syst. Sci., 15, 2303-2316, https://doi.org/10.5194/hess-15-2303-2011, 2011.

Topp, G. C., Davis, J. L., and Annan, A. P.: Electromagnetic determination of soil water content: Measurements in coaxial transmission lines, Water Resour. Res., 16, 574-582, https://doi.org/10.1029/WR016i003p00574, 1980.

Ulaby, F. T., Dubois, P. C., and Van Zyl, J.: Radar mapping of surface soil moisture, J. Hydrol., 184, 57-84, https://doi.org/10.1016/0022-1694(95)02968-0, 1996.

U.S. Department of Agriculture: Soil Climate Analysis Network (SCAN), available at: https://www.wcc.nrcs.usda.gov/scan/ scan_brochure.pdf (last access: 13 November 2017), 2016.

Van Emmerik, T., Steele-Dunne, S. C., Judge, J., and Van de Giesen, N.: Impact of Diurnal Variation in Vegetation Water Content on Radar Backscatter from Maize During Water Stress, IEEE T. Geosci. Remote Sens., 53, 3855-3869, https://doi.org/10.1109/TGRS.2014.2386142, 2015.

Van Genuchten, M. T.: A Closed-form Equation for Predicting the Hydraulic Conductivity of Unsaturated Soils, Soil Sci. Soc. Am. J., 44, 892-898, https://doi.org/10.2136/sssaj1980.03615995004400050002x, 1980.

Van Reeuwijk, L. P.: Procedures for soil analysis, Int. Soil Ref. Inf. Cent., 120, available at: http://www.isric.org/sites/default/files/ ISRIC_TechPap09.pdf (last access: 13 November 2017), 2002.

Varble, J. L. and Chávez, J. L.: Performance evaluation and calibration of soil water content and potential sensors for agricultural soils in eastern Colorado, Agric. Water Manag., 101, 93-106, https://doi.org/10.1016/j.agwat.2011.09.007, 2011.

Van der Velde, R., Su, Z., Van Oevelen, P., Wen, J., Ma, Y., and Salama, M. S.: Soil moisture mapping over the central part of the Tibetan Plateau using a series of ASAR WS images, Remote Sens. Environ., 120, 175-187, https://doi.org/10.1016/j.rse.2011.05.029, 2012.

Van der Velde, R., Salama, M. S., Eweys, O. A., Wen, J., and Wang, Q.: Soil Moisture Mapping Using Combined Active/Passive Microwave Observations Over the East of the Netherlands, IEEE J. Sel. Top. Appl. Earth Obs. Remote Sens., 8, 4355-4372, https://doi.org/10.1109/JSTARS.2014.2353692, 2014.

Vaz, C. M. P., Jones, S., Meding, M., and Tuller, M.: Evaluation of Standard Calibration Functions for Eight Electromagnetic Soil Moisture Sensors, Vadose Zo. J., 12, vzj2012.0160, https://doi.org/10.2136/vzj2012.0160, 2013.
Vereecken, H., Huisman, J. A., Bogena, H., Vanderborght, J., Vrugt, J. A., and Hopmans, J. W.: On the value of soil moisture measurements in vadose zone hydrology: A review, Water Resour. Res., 44, W00D06, https://doi.org/10.1029/2008WR006829, 2008.

Vereecken, H., Huisman, J. A., Pachepsky, Y., Montzka, C., Van der Kruk, J., Bogena, H., Weihermüller, L., Herbst, M., Martinez, G., and Vanderborght, J.: On the spatio-temporal dynamics of soil moisture at the field scale, J. Hydrol., 516, 76-96, https://doi.org/10.1016/j.jhydrol.2013.11.061, 2014.

Verhoef, A., Fernández-Gálvez, J., Diaz-Espejo, A., Main, B. E., and El-Bishti, M.: The diurnal course of soil moisture as measured by various dielectric sensors: Effects of soil temperature and the implications for evaporation estimates, J. Hydrol., 321, 147-162, https://doi.org/10.1016/j.jhydrol.2005.07.039, 2006.

Vernes, R. W. and Van Doorn, T. H. M.: Van Gidslaag naar Hydrogeologische Eenheid - Toelichting op de totstandkoming van de dataset REGIS II, Utrecht, the Netherlands, available at: https://www.dinoloket.nl/sites/www.dinoloket.nl/files/file/ dinoloket_toelichtingmodellen_20131210_01_rapport_nitg_ 05_038_b0115_netversie.pdf (last access: 13 November 2017), 2005 (in Dutch).

Wagner, W., Hahn, S., Kidd, R., Melzer, T., Bartalis, Z., Hasenauer, S., Figa-Saldaña, J., De Rosnay, P., Jann, A., Schneider, S., Komma, J., Kubu, G., Brugger, K., Aubrecht, C., Züger, J., Gangkofner, U., Kienberger, S., Brocca, L., Wang, Y., Blöschl, G., Eitzinger, J., Steinnocher, K., Zeil, P., and Rubel, F.: The ASCAT Soil Moisture Product: A Review of its Specifications, Validation Results, and Emerging Applications, Meteorol. Zeitschrift, 22, 5-33, https://doi.org/10.1127/09412948/2013/0399, 2013.

Wanders, N., Karssenberg, D., de Roo, A., de Jong, S. M., and Bierkens, M. F. P.: The suitability of remotely sensed soil moisture for improving operational flood forecasting, Hydrol. Earth Syst. Sci., 18, 2343-2357, https://doi.org/10.5194/hess-18-2343$2014,2014$.

Wang, H., Li, X., Long, H., Xu, X., and Bao, Y.: Monitoring the effects of land use and cover type changes on soil moisture using remote-sensing data: A case study in China's Yongding River basin, Catena, 82, 135-145, https://doi.org/10.1016/j.catena.2010.05.008, 2010.

Wilhite, D. A. and Glantz, M. H.: Understanding: the Drought Phenomenon: The Role of Definitions, Water Int., 10, 111-120, https://doi.org/10.1080/02508068508686328, 1985.

Wood, E. F., Roundy, J. K., Troy, T. J., Van Beek, L. P. H., Bierkens, M. F. P., Blyth, E., De Roo, A., Döll, P., Ek, M., Famiglietti, J., Gochis, D., Van de Giesen, N., Houser, P., Jaffé, P. R., Kollet, S., Lehner, B., Lettenmaier, D. P., Peters-Lidard, C., Sivapalan, M., Sheffield, J., Wade, A., and Whitehead, P.: Hyperresolution global land surface modeling: Meeting a grand challenge for monitoring Earth's terrestrial water, Water Resour. Res., 47, W05301, https://doi.org/10.1029/2010WR010090, 2011.

Wösten, J. H. M., Veerman, G. J., De Groot, W. J. M., and Stolte, J.: Waterretentie- en doorlatendheidskarakteristieken van bovenen ondergronden in Nederland: de Staringreeks (in Dutch), Alterra Rep. 153, 86, available at: http://edepot.wur.nl/43272 (last access: 13 November 2017), 2001.

Wösten, J. H. M., De Vries, F., Hoogland, T., Massop, H., Veldhuizen, A., Vroon, H., Wesseling, J., Heijkers, J., and Bolman, A.: BOFEK2012, de nieuwe, bodemfysische schematisatie van 
Nederland, Alterra Rep. 2387, 92, available at: http://edepot.wur. nl/247678 (last access: 13 November 2017), 2013 (in Dutch).

Xia, Y., Sheffield, J., Ek, M. B., Dong, J., Chaney, N., Wei, H., Meng, J., and Wood, E. F.: Evaluation of multi-model simulated soil moisture in NLDAS-2, J. Hydrol., 512, 107-125, https://doi.org/10.1016/j.jhydrol.2014.02.027, 2014.

Zacharias, S., Bogena, H., Samaniego, L., Mauder, M., Fuß, R., Pütz, T., Frenzel, M., Schwank, M., Baessler, C., ButterbachBahl, K., Bens, O., Borg, E., Brauer, A., Dietrich, P., Hajnsek, I., Helle, G., Kiese, R., Kunstmann, H., Klotz, S., Munch, J. C., Papen, H., Priesack, E., Schmid, H. P., Steinbrecher, R., Rosenbaum, U., Teutsch, G., and Vereecken, H.: A Network of Terrestrial Environmental Observatories in Germany, Vadose Zo. J., 10, 955-973, https://doi.org/10.2136/vzj2010.0139, 2011.
Zhang, X., Zhang, T., Zhou, P., Shao, Y., and Gao, S.: Validation Analysis of SMAP and AMSR2 Soil Moisture Products over the United States Using Ground-Based Measurements, Remote Sens., 9, 104, https://doi.org/10.3390/rs9020104, 2017.

Zheng, D., Van der Velde, R., Su, Z., Wang, X., Wen, J., Booij, M. J., Hoekstra, A. Y., and Chen, Y.: Augmentations to the Noah Model Physics for Application to the Yellow River Source Area. Part I: Soil Water Flow, J. Hydrometeorol., 16, 2659-2676, https://doi.org/10.1175/JHM-D-14-0198.1, 2015. 